Portland State University

PDXScholar

Spring 5-16-2018

\title{
India's Economic Growth: Role of Political Performance and Gender Wage Gap
}

Rajeev Indira Nagaraju

Portland State University

Follow this and additional works at: https://pdxscholar.library.pdx.edu/open_access_etds

Part of the Labor Economics Commons, Public Affairs Commons, and the Public Policy Commons Let us know how access to this document benefits you.

\section{Recommended Citation}

Indira Nagaraju, Rajeev, "India's Economic Growth: Role of Political Performance and Gender Wage Gap" (2018). Dissertations and Theses. Paper 4370.

https://doi.org/10.15760/etd.6254

This Dissertation is brought to you for free and open access. It has been accepted for inclusion in Dissertations and Theses by an authorized administrator of PDXScholar. Please contact us if we can make this document more accessible: pdxscholar@pdx.edu. 
India's Economic Growth: Role of Political Performance and Gender Wage Gap

by

Rajeev Indira Nagaraju

A dissertation submitted in partial fulfillment of the requirements for the degree of

\author{
Doctor of Philosophy \\ in \\ Public Affairs and Policy
Dissertation Committee:
Birol Yesilada, Chair
David Kinsella
Craig Shinn
Veronica Dujon

Portland State University

2018 
(C) 2018 Rajeev Indiranagaraju 


\begin{abstract}
This dissertation will explore how gender wage gap and political capacity represented by relative political extraction affect change in economic growth rate of a country. The main argument of the study is that gender wage gap is affecting the labor market by discouraging productive female labor force from entering the labor market. This in turn affects the efficiency and productivity of the labor market reflected in negative economic growth or economic growth potential being compromised. Here the case of Indian economy is examined. The important policy implication of this study is that it could account for the wage differential between genders and it could show how economies are missing out on the labor productivity and in turn negatively affecting the rate of economic growth.
\end{abstract}

Various sociological literatures have dealt in depth with the gender wage gap and its effect on the socio-cultural fabric of a society (Lips, 2012; Ochsenfeld, 2014; Alksnis and etal, 2008). While the current study recognizes existence of extensive sociological theories on gender wage gap, the focus is on the economic impact of gender wage gap on the growth rate change of a country. The argument is that gender wage gap negatively affects the economic growth rate change.

Economic growth literature have proved beyond doubt that economic and political factor together contribute to the economic growth of a country. Political variables such as political capacity reflects the efficiency of the government in resource extraction, its reach and allocation of those resources extracted. Such an efficient government provides 
the necessary environment for the economic growth. However, this political variable alone is not enough to increase economic growth of an economy. Rather governments must also possess the economic tools necessary, such as capital stock, human labor and labor force.

These economic and political variable together can contribute towards an increase economic growth. How these political and economic factors combine to achieve economic growth of a country? Hence this study looks at both the economic and political variables in a model to see how they affect economic growth. This research is in the context of Indian economy. 


\section{Acknowledgements}

I am immensely thankful to my dissertation committee members for their guidance. I am grateful to have a distinguished members in my committee whose immense knowledge and understanding on the subject has helped me in completing my dissertation. I am ever thankful to my advisor prof. Birol Yesilada for his constant advice on the subject matter and his support for the completion of this dissertation. I would like to thank Dr. Craig Shinn for helping me in understanding the theoretical nuances and concepts during my doctoral program. My regards to Dr. Ron Tammen for his willingness to be part of my committee. I would also like to thank Dr. David Kinsella for his constant pursuit in helping me write my thoughts clearly and cogently.

I cannot thank Mukunda Upadhayay enough for all his help with the data collection and validating my models and results. I am thankful to Dr.Veronica Dujon who not only served as graduate representative but also provided valuable insights with her thoughts that helped my dissertation.

I am grateful to all my colleagues at Portland State University who had made my doctoral program journey comfortable and meaningful.

Finally, without the love and support of my family I would not have been what I am today. My parents have always encouraged me in all my endeavors. My wife, Jyothi and my daughter Chasvi have been pillars of support and encouragement and have stood by me through the ups and downs of my life. 
Table of Contents

Page

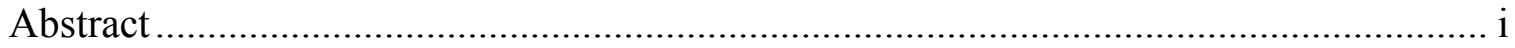

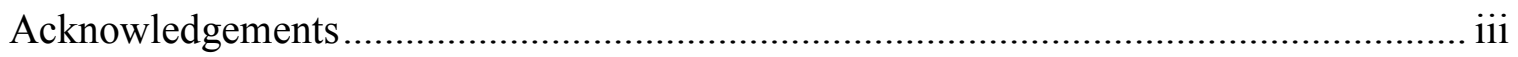

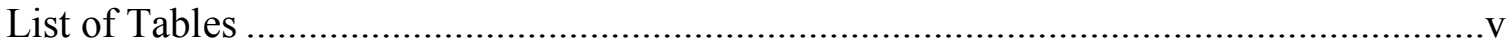

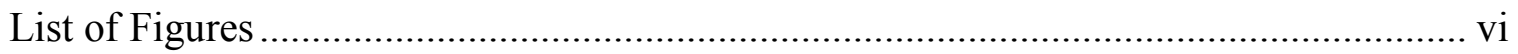

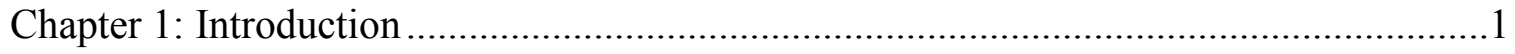

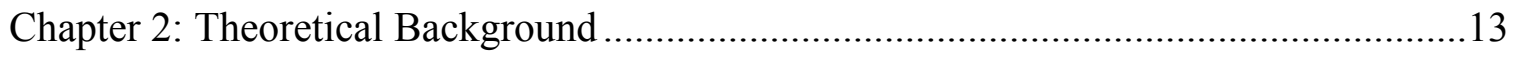

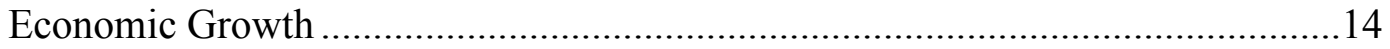

Economic Growth Studies in India ...............................................................26

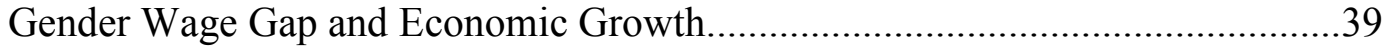

Literature on Measuring Gender Wage Gap ................................................43

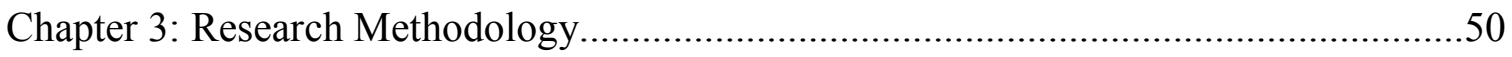

Definition and Measure of Variable Terms ...................................................51

Chapter 4: Economic Growth and Productivity: Analysis and Findings .........................61

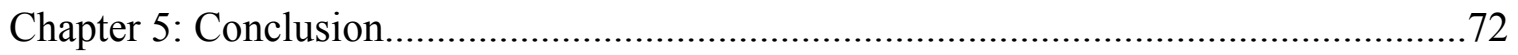

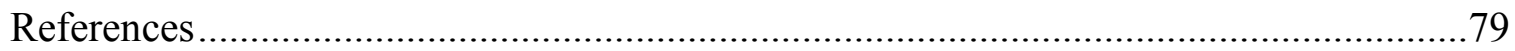

Appendices

Appendix A Normality Test of Models .......................................................... 89

Appendix B Statistical Tests for Models ..........................................................90

Appendix C Data Definitions and Sources .......................................................92 


\section{List of Tables}

Table $\quad$ Page

1 Percentage of Sector-Wise Composition of GDP in India (1950-2010) .............35

2 Sector-Wise Growth Rate and Gross Investment in India During

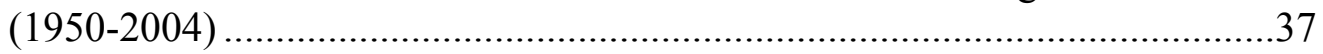

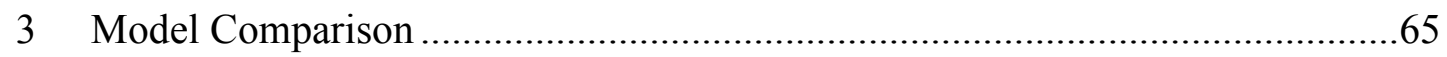

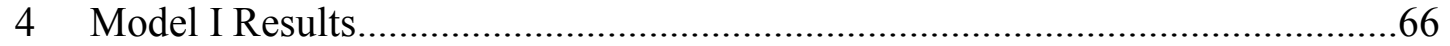

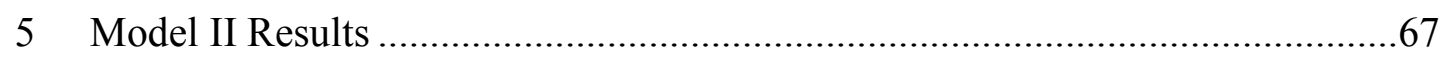

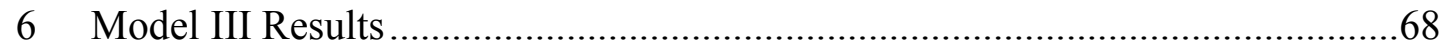




\section{List of Figures}

Figure $\quad$ Page

1 Investment, Trade and Government Expenditure as Ratio of GDP

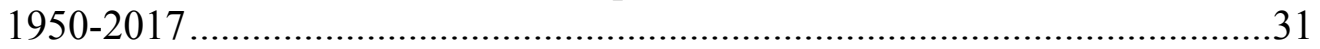

2 Trends in Government Expenditure and Per-Capita Real Income in India

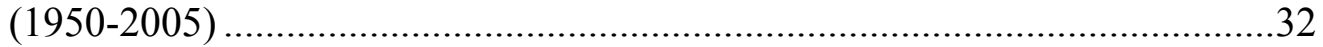

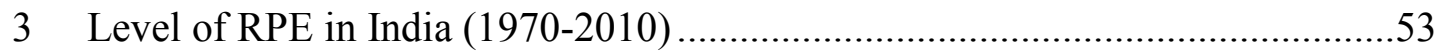

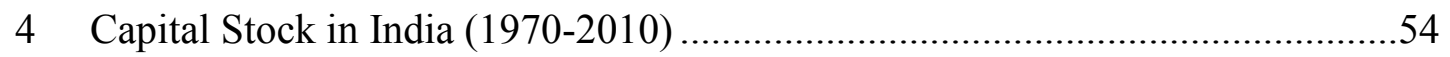

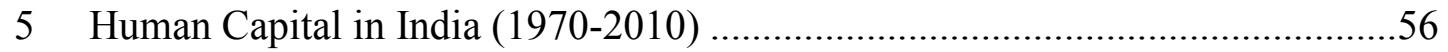

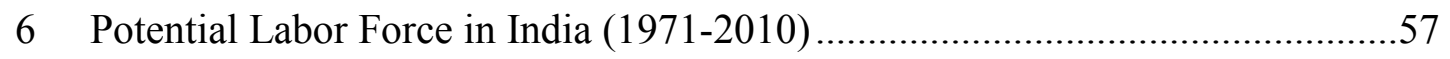

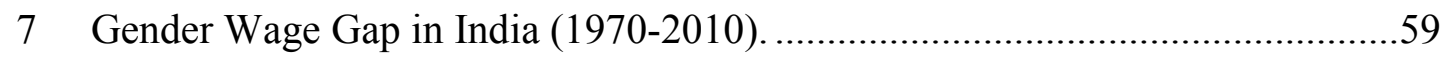




\section{Chapter 1: Introduction}

Economic growth and development have been one of the top priorities of India's government since the nation obtained its independence from British colonial power. In his first speech as Prime Minister, Jawaharlal Nehru stressed the importance of economic growth for the development of young democracy and to make a mark on the international arena. Accordingly, the economy was put on a 5-year plan to increase economic growth. Successive 5-year plans thereafter adopted various approaches with an ultimate goal of increasing economic growth in India.

This dissertation explores how gender wage gap and political capacity represented by relative political extraction effect economic growth rate change in India. The main argument of the study is that gender wage gap and relative political extraction have an impact on the economic growth rate change of India. While the gender gap negatively affects the growth rate change by failure to attract a productive human capital of female labor force from entering the labor market, relative political extraction can positively impact economic growth rate change through efficiency in resource extraction. The policy implication to this study is important because it could account for the wage differential between gender (that is male and female labor) and its negative impact on the economic growth rate change.

Literature on economic growth has proved beyond doubt that economic and political factors together contribute to the economic growth of a country (Gemmell, 1995, 1996; Krieckhaus, 2002; Mankiw, Romer, \& Weil, 1992; Poot, 2000). Political variables, such as political capacity, reflect the efficiency of the government in resource extraction, 
its reach and allocation of those resources extracted (Kugler \& Tammen, 2012). Such an efficient government provides the necessary environment for the economic growth. However, this political variable alone is not enough to increase economic growth of an economy. Rather governments must also possess the economic tools necessary, such as capital stock, human labor and labor force.

Economists have developed various economic growth models that can aid development of a society. However, there is “. . . no single empirical model of economic development that can be applied to all societies" (Mbaku, 1994, p. 3). Economic growth is one of the indicators to measure economic development. Studies abound that identify the various causes of economic development. While some identify the effects of liberties (civil, political and economic) on economic development (Pourgerami \& Assane, 1992), others conclude that the "choice of the institutional framework has profound consequences on the efficiency and growth of economies" (Scully, 1988, p. 661).

Economic growth is one of the important indicators of the health of an economy. The current research study clearly recognizes the difference between growth and development and also the argument that economic growth does not always translate into development (Umar, 2011). However, economic growth can be considered one of the important factors that can facilitate development. Further literature on economic growth studies in India have emphasized the traditional role of state and other socioeconomic factors impact the economic growth in India (Basu \& Maertens, 2007; Bhagwati \& Panagariya, 2013; Dash \& Sahoo, 2010; Mukherji, 2009). 
One of the significant independent variables considered for the study is gender wage gap. In the sociological field, the literature has dealt in-depth about the gender wage gap and its effect on the sociocultural fabric of a society (Menon \& Rodgers, 2009; Olsen \& Sexton, 1996; Polachek, 1987; Robinson, 1998; Shenhav \& Haberfeld, 1992; Terrell, 1992; Weichselbaumer \& Winter-Ebmer, 2005). Further literature on the gender wage gap covers various socioeconomic perspectives on gender wage gap (Chamarbagwala, 2006; Grybaite, 2006; Huang, 1999; Mincer, 1958; Weichselbaumer \& Winter-Ebmer, 2005). Theories such as occupational segregation, human capital model and labor market discrimination represent socioeconomic perspective on gender wage gap. Further, perspectives such as those of liberal feminists argue that the gender wage gap is the tool that is used to exploit particular gender (here women) to maximize the profit. The neo-liberal sociologists argue that pay gap is not due to discrimination but due to the type of jobs women choose. Akin to occupational segregation model, they believe that women work in female-dominated jobs that are set up at low pay. In other words, "pink collar" jobs that are dominated by women tend to get less pay than the traditional male jobs (Democratic Socialists of America, n.d.)

Human capital model argues that the cause of gender pay gap is the acquisition of abilities and skills in the form of education, training and experience. Discrimination in acquiring human capital which tends to favor men is the reason for existing gender wage gap. Due to difference in the human capital, women tend to apply for jobs that require less specialized skills and less experience. 
Labor market discrimination stream of thought argues that there is inherent discrimination in the labor market between men and women. Labor market discrimination affects women negatively through both wages received and the access to certain type of occupation. Such discrimination can take many forms such as economic discrimination, statistical discrimination and crowding (Grybaite, 2006) Economic discrimination is where an identical work and skill sets receive different pay based on gender. Becker (1971), who analyzed economic discrimination, has the belief that humans as utilitymaximizing individuals and firms as a profit-maximizing entity tend to discriminate against particular gender, that is, women. Such economic discrimination manifests in the form of employer discrimination, employee discrimination and customer discrimination.

Another model within the board stream of labor market discrimination thought is the model of statistical discrimination (Phelps, 1972). The main argument is that employers tend to judge women as average because they believe women are not career oriented and tend to quit job once they have kids.

Occupational Segregation thought of gender discrimination is represented in the model of Crowding developed by Bergmann (1974). Crowding model, as argued by Bergmann, suggests that with the denial of access to many jobs, women tend to crowd toward limited number of jobs available. Such jobs that are crowded by women are low paying jobs and hence are segregated to certain types of jobs.

While the current study recognizes existence of extensive sociological theories such as human capital model, occupational segregation model and labor market discrimination theory on gender wage gap, the focus is on the economic impact of gender 
wage gap on the growth rate change of a country. The argument is that gender wage gap negatively affects the economic growth rate change. There is relatively scant literature on the impact of gender wage gap on economic growth in India. This study attempts to fill that void in the literature by looking at how gender wage gap affects economic growth in India at a given level of political capacity of the government.

Another variable considered for the study is political capacity. Political capacity of the government refers to the "... ability of the governments to reach their population, to extract economic resources from that population, and to allocate those resources to secure the long-term survival of the political structure" (Kugler \& Tammen, 2012, p. 8). There are three measures to gauge the political capacity of a government, namely, Relative Political Extraction (RPE), Relative Political Reach and Relative Political Allocation. Each of these measures reflects the efficiency of the government in reaching its policy objectives and development goals. The study uses the measure of RPE to see whether political capacity of a government along with other economic factors contributes to economic growth.

As a measure of political capacity RPE refers to ". . . the ability of a government to obtain resources from a population given their level of economic development" (Kugler \& Tammen, 2012, p. 13). The RPE indicator is measured at actual level against the predicted level.

The role and importance of a stable government are underscored by the recent political events across middle-east and North Africa (Tunisia, Libya, Egypt and Iraq) and the relative struggle in these countries to establish stability in political structure and 
achieve economic growth. This situation of lack of established and legitimate governing structures emphasize and reiterate the importance of government for stability and economic growth of a nation. Further an efficient government can go long way in improving the lives of its citizen through maximizing the utilization of its resources (both physical and human) and allocation of the acquired resources among its citizens. Accordingly, the current study incorporates the role of political capacity of a government, here expressed in terms of RPE in relation to its influence on economic growth.

The study differs from the existing approaches to the study of economic growth in several ways. First, it incorporates the gender wage gap model into political performance, labor efficiency and economic growth (Seguino, 2000a). Most literature on the gender wage gap looks at the concept of wage gap from the sociological perspective of women as a gender within a society and how gender biases toward women are reflected in their wages. Further the existing literature on gender wage gap looks at the effect of gender wage gap on socioeconomic and political conditions of women. But the studies that explore a systemic approach to gender wage gap and economic growth are scant. In other words, how the gender wage gap effects the system in terms of labor efficiency by depriving the labor market the most productive labor force and thereby in turn affecting the economic growth of a system. Further, the study incorporates a political economy approach by looking at the linkage between political performance, gender wage gap, human capital and economic growth.

These economic and political variables together can have an impact on economic growth. How do these political and economic factors combine to achieve economic 
growth of a country? Hence I look at both the economic and political variables in a model to see how they affect economic growth. With this background, the current study sets out to explore the factors affecting the economic growth in India. This research is in the context of Indian economy.

The main thesis of the study is that gender wage gap has negative impact on economic growth whereas government with an efficient resource extraction capability has a positive impact on economic growth. Negative impact of gender wage gap on economic growth can be through discouragement of women labor from entering the labor market there by depriving the labor market of its productive labor, which in turn impacts economic growth. Another negative impact of gender wage gap is that it also deprives the valuable human capital (skills set among the female labor) from getting utilized towards economic growth. On the other hand governments through efficient resource extraction can utilize its physical and human resources toward increased economic growth. Further there is a two-way relationship between reduction of gender wage gap and increased political capacity of a government. The effective utilization of productive labor into economic activity helps the government improve the measures of political capacity such as RPE by increasing the economic base of the resource extraction in terms of increased taxpayers.

The causes of economic growth have undergone constant analysis by researchers who attempt to understand the phenomenon. Mainstream perspectives such as classical political economy have a history of emphasizing the study of long run economic growth. The neoclassical economic growth model of Solow analyzed economic growth as 
dependent on the availability of total capital stock, labor stock and the given level of technology.

Mbaku (1994) argued that paradigms of economic growth can be classified into two main streams, first Statism, which emphasizes the role of the state in economic growth and second, Individualism, which gives importance to individual and private initiative in economic growth. Individualists argue that private enterprises and markets best determine the resource production and allocation leading to welfare and growth of the economies (Carroll, Conant, \& Easton 1987; Moralock \& Vitton 1985; Nelson, 1992). Statists believe that state is the prime facilitator of economic growth. The state acts as a conflict reducing agent, prevents exploitation of people, and increases productivity through appropriate policies (Mbaku, 1994) Furthermore, the state provides the "socially optimal direction for growth and development" (Ram, 1986, p. 191). Emphasizing the role of the state and politics in economic growth, the political economy approach to growth argues that "... economics alone cannot fully explain the enormous variance across countries in growth and ... economic policy choices are not made by social planners, who live only in academic papers. Rather, economic policy is the result of political struggle within an institutional structure" (Alesina \& Perotti, 1994, p. 351).

Contextualizing the scope of the study, the current study is focused on the Indian economy. India is one of the fast-growing economies, in terms of the economic growth rate, consistently notching more than $5 \%$ annual growth rate for more than a decade (Obiols, n.d.). Subsequently, understanding the phenomena of economic growth in India 
is key to gaining a better comprehension of the nuances of contemporary global economic phenomena.

Further, India and China have the highest labor force in the world that are employable but India has the lowest rate of labor force participation. Furthermore, India also has one of the lowest rates of women's participation in the labor force and the male/ female gap in the labor force has been the highest (U.S. Bureau of Labor Statistics, 2012).

The argument of untapped workforce potential in India is put forward in a study conducted by Gupta (2007) in collaboration with Watson Wyatt Worldwide. Exploring India's skilled labor supply, the author argued that India is far from being a global destination for skilled labor supply. It was further suggested that India needs to improve its educational system and include the largely untapped labor pool of skilled Indian women.

Gupta (2007)

... concludes that despite its large talent pool of skilled workers, India will have to work hard to meet the rapidly growing global demand for skilled labor .... India would be unlikely to surpass the skilled labor supply of United States in the next 20 years, because a large proportion of its population with a college degreemainly women - will not be participating in the workforce. An important challenge for employers is to devise ways to attract and retain this untapped talent pool. Benefits such as flexible working hours, telecommuting and maternity leave, in addition to competitive salaries, might encourage many women to change their minds about working outside of the home. (p. 3)

There is a relative increase in the skilled labor force of women but such an increase is not reflected in the actual participation of women in the labor market. "In fact between 1999 and 2004, the average annual growth rate in skilled women (7\%) was about 1.5 times higher than the growth rate in skilled men" (Gupta, 2007, p. 5). It would 
be a challenge for the employers in India to tap the pool of skilled Indian women and their participation in the labor market. In this context comprehending the productivity of the labor relative to gender is important as it will provide a clear understanding of the labor productivity and its influence on economic growth.

The scholars have started looking into the gender difference in terms of wages and the impact of such wage gaps on various aspects of the economy.

There is a growing research interest in the gender effects of trade policies ... with a relatively large emphasis on labour market outcomes. In particular, the impact of trade reforms and globalisation on relative female wage and employment positions within the labour market is one area that has attracted some attention. The emphasis on the labour market is apposite as it generally provides the conduit through which reform policies impact on a country's standard of living .... Labour market earnings remain an important component of household income in many developing economies and provide a direct link between household welfare and economic activity. The labour market is justifiably viewed as the key market through which the rewards of economic reforms are ultimately conveyed. (Reilly \& Dutta, 2005, p. 1)

In India there has been a steady decline of the productive women labor force participation in the labor market over the decade from $40 \%$ in 1983 to $38.6 \%$ in $2004-$ 2005 (Bhalla \& Kaur, 2011). In other words, increasing number of skilled women labor force is not reflected in participation of such skilled labor in the labor market. The survey conducted by World Economic Forum's Global Gender Gap Report 2009 puts India at 127th rank out of 134 countries in economic participation and opportunity for women labor. "Indian women now represent $40 \%$ of students enrolled in college, with many earning degrees in science and engineering ...” (Schomer, 2010, p. 5). However, such development of talent and potential labor among women in India is not reflected in the labor force participation. 
Why has there been a low participation of females in the labor force in India? Does the wage gap based on gender have any role in such low rate participation of women in productive economic activity, and, in turn, economic growth? Can political capacity of a government measured in terms of resource extraction, influence the productive labor force participation leading to better economic growth. Understanding wage gaps among the labor force and how it affects economic growth will help to comprehend labor productivity along gender lines and help answer the questions raised above. At the same time an efficient government that can extract and utilize its resources (both physical and human) can be solution in dealing with low rate participation of productive female labor. Accordingly, the current study is an attempt to analyze economic growth through the angle of gender wage gaps with a given level of political capacity.

This dissertation is divided into five chapters. The first chapter is the current chapter of introduction. The second chapter deals with the literature review on economic growth, labor efficiency and gender wage gaps. Analyzing various literatures and arguments in the field of economic growth, the chapter attempts to identify the existing literature in the respective field and the theoretical background of such literature. The purpose is to identify the gaps in the existing literature and how the current study would be aiming to add to the existing literature, and, fill the void in already existing body of literature relating to gender wage gap and economic growth in India.

Chapter Three narrates the research methodology adopted in the research study. The chapter discusses the statistical model used to analyze the research study. A detailed 
discussion of the time series regression model along with the description of the dependent and independent variables forms the major part of the third chapter. Subsequently, the chapter discusses how the dependent and independent variables are defined and how are they measured in the model of analysis.

Chapter Four analyzes the models that were laid out in the Chapter Three. Accordingly, the analysis focuses on the impact of labor force, capital stock and political extraction and gender wage gap towards economic growth. Three models were analyzed and coefficients of the respective independent variables were reported vis-a-vis dependent variable to show the level of significance in impacting the economic growth. Besides, the results of the analysis are reported along with the policy implications. Such policy implications are related to formulation and enforcement of competitive wages irrespective of gender to attract efficient labor into the market. Also, efficient policies related to resource extraction in the form of tax reforms. The final chapter discusses the conclusion and limitations of the study and offers scope for further research. 


\section{Chapter 2: Theoretical Background}

This chapter provides theoretical context to the current research study. The first section of the chapter explores the various theoretical and empirical literatures on economic growth and contextualizes the literature against the current study. Next, various theories and literature on gender wage gap are analyzed. Finally, literature on the empirical studies on economic growth in India is examined. The purpose of the above discussion and exploration of the literature on the topics is to provide a brief overview of the existing literature in these areas and then identify the gap in the literature leading to how the current research would fill in the gap in the literature and add to the existing body of literature.

In the process, the chapter tries to tackle some of the following questions: Is economic growth mostly related to factors of production along with the policies of government? Or, is economic growth the result of better governance structure and institutions along with economic factors? What is the role of government in coordinating various sectors, such as, primary, secondary and tertiary sectors of the economy toward economic growth? What is the role of various forms of capital, namely, physical, human and social capital in economic growth? How does economic growth effect and get affected by various socioeconomic and political factors within a country? The above questions are worth considering for any country working toward better economic growth. Literature on the above issues has been discussed extensively in various academic fields such as economics, political science, sociology, development studies and urban studies. To address these issues, it is important to understand the concept of economic growth. 
What is meant by economic growth and how do we measure it? What is political performance and why it is relevant to the current study? The main economic and political determinants of economic growth considered in this research include physical capital stock, human capital stock, and gender wage gap in the labor market, RPE as measure of political performance in assessing the capability of national government of India.

\section{Economic Growth}

Economic growth is one of the important objectives of any economy. Contextualizing the current research paper within the broad theoretical literature on economic growth, the following section discusses the literature on economic growth within a given theoretical framework. Accordingly, literatures on various theories of economic growth are analyzed here. Within the economic growth accounting literature, economic growth models can be broadly classified as endogenous and exogenous economic growth models.

Exogenous economic growth model. Exogenous growth theory believes that the growth occurring within an economy is influenced by the external factors/forces. The exogenous growth model has its connection to neoclassical theory of economic growth, because neoclassical theory of economic growth assumes that technology required for economic growth is exogenous and also in terms of assumptions and questions about economic growth (Solow, 1956).

One of the main tenets of Neo Classical theory of economic growth represented in Solow's (1956) model is the concept of production function. Production function consists 
of capital, labor and technology as factors contributing to economic growth with technology being the exogenous factor. Prior to Solow's model of economic growth, economists Harrod (1939) and Domar (1946) proposed an economic growth model famously came to be known as Harrod-Domar model of economic growth. The assumption of the production function of this model is that there are constant returns to scale in terms of the factors of production also known as "fixed proportion assumption." In other words, the share of labor and capital in the growth are constant in the long run. Disagreeing with the fixed proportion assumption of Harrod-Domar model, Solow's economic growth model states that with a given level of savings, capital, and labor input there is an increase in economic growth output. Solow's model of economic growth states that the coefficients of production function is variable. In other words the ratio among the factors of production in a production function is not constant and in the long run, they adjust themselves toward equilibrium.

The exogenous growth model's recipe for success is that economies with higher investment in physical capital that have a high level of technology, low population rate and high level of labor productivity will experience better economic growth.

Endogenous economic growth model. The endogenous growth theory developed as a response to the criticisms of neoclassical models of economic growth. One of the criticisms of neoclassical model of economic growth is that it assumed the technological change was exogenously determined and hence the conclusion that government and market policies could do nothing to increase economic growth in the long term. Alternatively, the endogenous growth theory suggests that technological change is a 
response to economic incentives in the market that can be created and affected by government or private sector institutions.

One of the important differences between endogenous and exogenous models is that the endogenous growth theory argues that economies do not reach stability, as economies achieve constant returns to capital. Endogenous model also asserts that the rate of economic growth is dependent on whether the country invests in technological or human capital.

There are several policy implications of endogenous growth theory. First and foremost is the conclusion that policy and institutions do matter and can have an effect on growth. Rather than countries having to wait for exogenous technological progress to occur or being limited to short-term increases in growth that result from policy-induced increases in the savings rate, endogenous growth theory suggests that government and private sector policies can have an effect on long-term growth.

Mankiw et al. (1992) critically evaluated the Solow model and improved the Solow model by adding the variable of human capital. Through education, training and other investments in human capital, a country can increase worker productivity and increase economic growth.

Within the same tradition of endogenous growth model, Gemmell (1996) constructed an alternative measurement to capture the human stock accumulation and its effects on economic growth. Gemmell stated that most of the economic growth models that employ the human capital variable in their economic growth model consider school enrollment rates as a proxy for human capital (Barro \& Lee, 1996; Baumol, 1986; 
Mankiw et al., 1992; Romer, 1990). But, Gemmell argued that it is unclear whether such analysis indicates "stock" or "flow" effects of human capital on economic growth (Gemmell, 1996, p. 12). In other words, Gemmell has the belief that economic growth is influenced by the initial level of human capital stock and argued that using school enrollment as a proxy for human capital will fail to account for influence of initial level of human capital stock on economic growth.

Surveying the empirical economic growth literature, Sala-i-Martin (1993) discussed certain findings that can influence the cross-sectional empirical analysis. Sala-i-Martin analyzed the important question of "convergence hypothesis" also known as beta-convergence among the growth researchers. The convergence hypothesis believes in the neoclassical assumption of diminishing returns of capital. Accordingly, the argument of the convergence hypothesis is that the level of initial capital affects the growth rate of an economy. If an economy has a high level of initial capital, its growth rate will be relatively slower than the country with a lower level of initial capital.

Critiquing the early neoclassical assumption of poor countries growing faster than rich countries, Barro (1993) and Sala-i-Martin (1994) and Mankiw et al. (1992) discussed "conditional convergence." The argument is

... that the growth rate of an economy would be inversely related to the distance from its steady state. Only if all economies were to converge to the same terminal point would poor countries grow faster than rich ones. But if one accepts that countries differ in their levels of technology, attitudes towards saving, tax rates, etc., then one must also accept that these countries will approach different steady states. The growth rate of an economy is then predicted to be inversely related to the distance from its steady state. The concept of convergence conditional on the steady state is a known as "conditional convergence." (Sala-i-Martin, 1994, p. 743) 
Further findings of Sala-i-Martin's (1994) include: (a) there are no evidences of absolute convergence across various economies, (b) investment rate has significant influence on the economic growth of an economy, (c) Countries with high skilled labor force grow faster compared to other countries, and (d) Effective government with good public policies has positive impact on economic growth.

The concept of conditional convergence was included as one of the determinants of economic growth by Barro and Lee (1993). Discussing some of the determinants of economic growth, Barro and Lee analyzed both the positive and negative determinants of economic growth. Education level and health of the population and high investment are the positive determinants of economic growth. The negative determinants of economic growth include extensive government expenditure, existence of parallel economy in the form of black market and lack of stable government (Barro \& Lee, 1993).

The current research study situates within the endogenous economic growth model. The study is examining the role of human capital and labor productivity by examining the role of gender wage gap affecting the labor productivity and in turn economic growth. From the above literature, it is clear that human capital and labor have been an important factor in the endogenous growth model. The current study attempts to expand the realm of endogenous growth literature by examining the gender wage gap within the model element of labor. Further, the study also recognizes the role of government and private market in the influencing the economic growth. The study adds to the already existing body of literature in endogenous model of economic growth by 
looking at the efficiency of the government (RPC) in utilizing its human resources and increasing labor productivity through reducing gender wage gap.

Empirical studies on economic growth. This section discusses the literature on empirical studies on economic growth. The attempt is to discuss literature on determinants/ factors of economic growth in an empirical context. Analyzing determinants of economic growth, Rock (1993) argued that the issues of inflation, the balance of payments and debt have come to play significant role post 1975 in affecting economic performance of a country.

Similarly, analyzing the importance of trade toward economic growth Feder (1982) discussed the role of productivity and positive externalities of export oriented industries on economic growth. Feder argued that export oriented industries contribute to better marginal productivity and positive externalities thereby contributing to higher economic growth.

Non-Economic determinants of economic growth. Exploring the literature on the non-economic determinants of economic growth, the studies by Pourgerami and Assane (1992) stressed the importance of political freedom on economic growth. Pourgerami and Assane argued that the social capabilities of the people within the country have significant impact on the income growth and in turn economic growth. Such social capabilities among the individuals within a country can be cultivated and developed by providing political freedom and greater control over self.

Continuing the discussion on the non-economic determinants of economic growth, Verdier (2002) discussed the political economy of growth by providing a review 
of various theories on how political institutions and policies affect the economic growth. Verdier focused on three main issues: "1) the modeling of dynamic political behavior; 2) the existence of multiple equilibria in growth and politics; 3) endogenous political systems and economic development." (p. 758). According to Verdier, the basic structure of the political economy model of growth should have three features.

First, it should identify a political conflict in a society. Therefore, it should capture some heterogeneity among agents. Second, it should specify political institutions providing a mechanism for these conflicts to be materialized into actual policies. Finally, it should describe the underlying dynamic economic framework to investigate the effects of policies on long-run performances. (p. 758)

Emphasizing the role of political bureaucracy, Spindler and Forrester (1993) argued the relative stability of the political bureaucracy has significant influence on the economic policy and growth. Such influences of political bureaucracy manifest in the form of support to the regime and maintaining the status quo in the development policies and economic growth model. Spindler and Forrester conclude that the real problem to economic policy is not the design of the policy but to remove the stranglehold of political bureaucracy on the development policies of a regime and the overall regime as such (p. 29).

Spindler and Forrester (1993) discussed the various models of economic development policies and categorize them into three broad frameworks. They are: (a) Causality framework based on economic rationale and derived from the locational model, (c) demand-side policies, and (c) Human capital Framework. Spindler and Forrester argued it is political or bureaucratic risk, which is important for policy makers to consider while dealing with economic development policy. 
Krieckhaus (2002) emphasized the role of the public sector in state-led economic growth through mobilization of financial resources for investment and growth. Krieckhaus built his argument through the concept of development states. Theory of development states' believes in the significant presence of bureaucracy that is independent of its society that can make optimal use of its resources toward growth. Further, discussing the various literature on developmental state theory, Krieckhaus emphasized the resource allocation and resource mobilization capability of the developmental state toward economic growth.

Taking further the concept of the developmental state discussed above by Krieckhaus (2002), Leftwich (1995), defined it

as states whose politics have concentrated sufficient power, autonomy and capacity at the center to shape, pursue and encourage the achievement of explicit developmental objectives, whether by establishing and promoting the conditions and direction of economic growth, or by organizing it directly, or a varying combination of both. (p. 401)

Leftwich (1995) outlined some of the characteristics of the developmental state.

They are: (a) a determined developmental elite; (b) a relative autonomy; (c) a powerful, competent and insulated economic bureaucracy; (d) a weak and subordinated civil society; (e) the effective management of non-state economic interests; and (f) repression, legitimacy and performance (p. 405).

Analyzing the regime type and economic growth, Feng (1995) argued that nonmilitary regimes are more favorable to economic growth than the military regime. The rationale for such an argument is that the various rights and liberties that are available in a non-military regime contribute to economic growth. 
Discussing specifically democratic regime and economic growth, three schools of thoughts are discussed by Sirowy and Inkeles (1990). The "conflict school" argues that democracy hinders economic growth, particularly in less developed countries. The assumptions in support of such a claim are basically threefold: "dysfunctional consequences" of "premature" democracy slow growth, democratic regimes are unable to implement effective policies necessary for rapid growth, and democracy is incapable of pervasive state involvement in the development process in the present world-historical context.

In contrast, the "compatibility" school of thought sharply objects to the assumptions of the "conflict school" and argues that democracy enhances economic growth. Proponents of the democratic model argue that a democratic government in the Third World is best suited to foster sustained and equitable economic development; their assumption is that democratic processes and the existence and exercise of fundamental civil liberties and political rights generate the social conditions most conducive to economic development.

Finally, the "skeptical" perspective does not seem to think that there is any systemic relationship between democracy and economic development (Pye, 1966). The proponents of this school of thought suggest that politics alone matter very little; instead, a focus should be placed on institutional structures (e.g., two-party vs. multi-party) and government development strategies (e.g., import substitution vs. export promotion) .... The skepticism in this perspective suggests that political systems themselves may not 
matter very much after they are controlled by economic conditions and policy instruments (Sirowy \& Inkeles, 1990).

Guseh (1997) argued that irrespective of regime type, the size of the government has an impact on the economic growth. Bigger size of government has negative impact on economic growth. However, increasing size of government in a non-democratic regime has threefold more negative impact on economic growth than the bigger government in a democratic regime.

Subsequently, analyzing the effect of government size on the economic growth, Chiou-Wei, Zhen, and Kuo (2010) argued that government size does impact economic growth. Chiou-Wei et al. determined an optimal point that is acceptable for the size of the government. If the size of the government exceeds that point then it starts to have a negative impact on economic growth.

On the other hand, Quang (2012) argued that increase in economic growth is directly related to the increased expenditure on per-capita public health, education, population growth and increased share of capital formation in total gross domestic product (GDP).

Furthermore, arguing for the need of government at various levels, Poot (2000) proposed several different areas where the government has an impact on long-run growth. Those areas are: (a) providing public goods, (b) banking, (c) taxes and resource allocation, (d) control and management of private goods that have both positive and negative externalities, (e) Handling the issue of equity, and (f) Mediating and facilitating market functioning. 
The empirical literature review of non-economic determinants of economic growth leads to exploring the cross-country analysis of the economic growth in relation to institutional structures and trade policies. Comeau (2003) compared the economies of Latin America and East Asia and thereby discussed the divergence in economic growth between two sets of countries from the regions who adopted similar development policies in the 1970s and 1980s. Comeau argued that "respective sociopolitical and institutional environment of the two regions was also an important factor contributing to their economic outcomes" (p. 476). Post Second World War, some of the economies of these regions have adopted similar policies of import-substituting industrialization as a strategy for economic growth. But the later part of the 1950s saw the shift in the policies adopted by the economies in East Asia. Through the analysis, Comeau argued that the policy choices played a crucial role in cross-regional differences in economic performance in the post-second world war era. Furthermore, Comeau has the belief that institutions and accommodation of multiple social interests is necessary for the economic growth.

Tang and Hedley (1998) explained the impact of the state and the presence of distributional coalitions or interest groups on the economic growth and development among countries. They conducted a geographical comparison of countries in two different continents attempting to explain why the Asian countries have outperformed Latin American countries in socioeconomic development. Comparing eight Newly Industrial Countries in Asia and 12 Latin American countries.

Tang and Hedley's (1998) literature review reflected that strong government has both positive and negative influences toward economic growth. Accordingly, Tang and 
Hedley applied the theory of distributional coalition to explain the domestic socioeconomic development of a country. Discussing the negative influences towards economic growth Olson believes that "... ultimate cause of economic growth lies in the growth-retarding effects of distributional coalitions or special interest groups, such as business and professional associations, labor unions, farmers' associations and other parochial self-serving interests" (Olson, 1982, p. 300).

Tang and Hedley (1998) synthesized the Olson's theory of distributional coalition with the statist approach. Statist approach believes in the independent nature of state in influencing and facilitating economic growth (Skocpol, 1979). Integrating the two approaches through considering the complex and mutual interaction between the state and distributional coalitions can possibly produce a better general explanatory model of economic development. This synthesis permits the following predictions: "nations with strong distributional coalitions will have slow economic growth and state intervention will be relatively ineffective; nations with weak distributional coalitions will have high economic growth rates and state intervention will be effective" (Olson, 1982, p. 302).

Feng (1995) argued that political and civil liberties contribute to economic growth. The analysis of economic growth and the political system shows the irrespective of the regime type, a civilian governed country tends to grow faster than a military government.

Thus, the above sub section of noneconomic determinants of growth has shown the how various constituents and institutions within state plays an important role in affecting and influencing economic growth. Further, the literature also showed that how 
state is one of the big players in mediating, facilitating and influence growth.

Accordingly, the current research study attempts to explore another dimension of state's role in economic growth by looking at the efficiency of government through the concept of Relative Political Capacity (RPC), which is explained in detail in the next chapter during the discussion of model specification.

\section{Economic Growth Studies in India}

This section of the chapter discusses literature on economic growth in India. Since the research study is limited to the Indian economy, exploring the literature on economic growth studies in India will help in situating the current study. In 1947 when India became independent from the British colonial rule, it had multiple strategies to choose for its economic growth. India came to adopt the strategy of "Five-Year Plans" (where economic growth strategies were formulated, target set and targets were revised at the end of every 5 years), with a bent on socialistic ideology. This ideological leaning had its effect on economic growth strategy of India in terms of limiting the growth potential. The following section deals with various literatures on economic growth studies in India.

There is a direct link between growth rates and policies. Historically, economic growth in India is inhibited by the government control over trade and investment, Panagariya (2008). The liberal economic policies started in the late 1980s and adopted full-fledged post-1990s have accelerated economic growth in India.

The socialist mindset of the leaders during the initial period of post-independent India had led to stagnant economic growth by inhibiting the growth potential of domestic economic forces. The argument is that the liberal economic policies and reforms adopted 
since 1990s led to accelerated economic growth in India. (Bhagwati \& Panagariya, 2013). Furthermore, Bhagwati and Panagariya, categorized the economic reforms in India into two categories, namely Track I reforms and Track II reforms. "Track I: reforms aimed at accelerating and sustaining growth while making it even more inclusive. Track II: reforms to make redistributive programs more effective as their scope widens. (Bhagwati \& Panagariya, 2013, p. 96)

Basu and Maertens (2007) explored India's economic growth and analyzed various factors that hindered as well as contributed to economic progress. Examining the historical economic growth data and the estimated sectoral statistics, Basu and Maertens concluded that even though the economic growth rate has shown promising results, there are certain areas such as infrastructure, labor and banking laws and corruption at government institutions that still needs improvement for sustaining and improving the current economic growth rate. In addition to the above lacunae, there are other areas such as the relatively lower growth rate of agriculture sector, disparities both at the state level and at the rural-urban level that need to be addressed so that there is an economic progress at the macro level.

Examining the role of state and its alliance with the society in obtaining a consensus toward policies, Mukherji (2009) argued that unlike other East and Southeast Asian countries, the Indian state had a strong role to play in adopting the appropriate policies toward economic growth and also obtaining the required social consensus toward such policies. However, adoption of necessary policies toward economic growth has been gradual. Such a gradual change in economic policies provided scope for correcting and 
avoiding the previous mistakes in the economic policies. Accordingly, the economic growth and change in India may be relatively slow compared to other countries but it is more stable due to the policy consensus obtained from the society.

Investigating the role of physical and social infrastructure on economic growth in India, Dash and Sahoo (2010) showed the impact of infrastructure on economic growth. The authors had developed a composite index of physical infrastructure stocks and then examined its impact on output. The data results indicated that physical and social infrastructures have a significant positive impact on output apart from gross domestic capital formation and international trade. The analysis further revealed that there was an unidirectional causality from infrastructure development and human capital to output in India. The rationale for such causality is that the infrastructure development will bring down the transaction costs that attract more investors along with huge capital investment which in turn lead to growth.

Underlining the importance of infrastructure to economic growth, Dash and Sahoo (2010) have the belief that reduction of transaction cost in the production of goods and services will have a significant impact on economic growth. They also argued that transaction cost can be reduced by improving the infrastructure and providing access to both the domestic and international stakeholder to be part of the production process (Dash \& Sahoo, 2010).

Rao and Vadlamannati (2011) applied the extended Solow growth model to argue that human capital has both level effects and growth effects on economic growth of India. 
. . . the estimates for India showed that the elasticity of the level of output with respect $\mathrm{H}$ [humancapital] is about 0.65 and that $\mathrm{H}$ permanently increases the rate of growth of output. The sample average $\mathrm{H}$ was 1.131 and implies that its contribution to India's growth rate was $1.7 \%$. If this is increased by $20 \%$, the permanent growth rate in India will increase to 2\%. (Rao \& Vadlamannati, 2011, p. 62)

Chakraborty and Nunnenkamp (2008), using Granger's causality test, analyzed the effect of industry-specific FDI on the economic growth in India. Addressing the issues of FDI post-1991 economic reforms in India, Chakraborty and Nunnenkamp argued that FDI impact on economic growth varies across the sectors of the Indian economy. Even though there was a greater flow of FDI into the service sector, it was the manufacturing sector that had the highest growth impact due to FDI flows. Chakraborty and Nunnenkamp summed up their results by stating that it is the economic growth that influence and impact FDI rather than the reverse. In other words, stronger economic growth attracts FDI than the other way.

Exploring the relationship between economic growth and poverty reduction in India, Ravallion and Datt (2002) attempted to answer the question of why economic growth has different effects on poverty reduction in different regions of India. Given the diverse experience of poverty reduction in relation to economic growth, Ravallion and Datt stated that

... that non-farm economic growth was less effective in reducing poverty in states with poorer initial conditions in terms of rural development (in both absolute terms and relative to urban areas), human resources and land distribution. The sectoral composition of economic growth was clearly more important to poverty reduction in states with poor initial conditions. (Ravallion \& Datt, 2002, p. 396)

Apart from the state's initial conditions, the literacy rate also plays an important part in the poverty reduction and pro-poor growth in India. 
M. Kumar (2011) argued that economic growth need not necessarily lead to convergence in the growth of its regions. He analyzed the economic growth rate of India between pre and post economic reforms era and concluded that even though there has been increasing economic growth it has not led to convergence in the economic growth rate of various states of India.

Exploring the direction of causality between financial development, inflation and economic growth in India, R. P. Pradhan (2011) argued that there is causal relationship between the inflation, financial development and economic growth. The empirical research by Pradhan showed that there is there is a two-way cause and effect relationship between economic growth and financial development where as such influence is one directional with regard to inflation, financial development and economic growth.

Dash and Sharma (2008) have the belief that there is a positive impact of government expenditure and economic growth. Analyzing the impact of government expenditure over economic growth in India during the period 1950-2006, the results indicated a significant positive impact of government expenditure toward economic growth. Figure 1 depicts trends in investment, trade and government expenditure as ratio of GDP. 


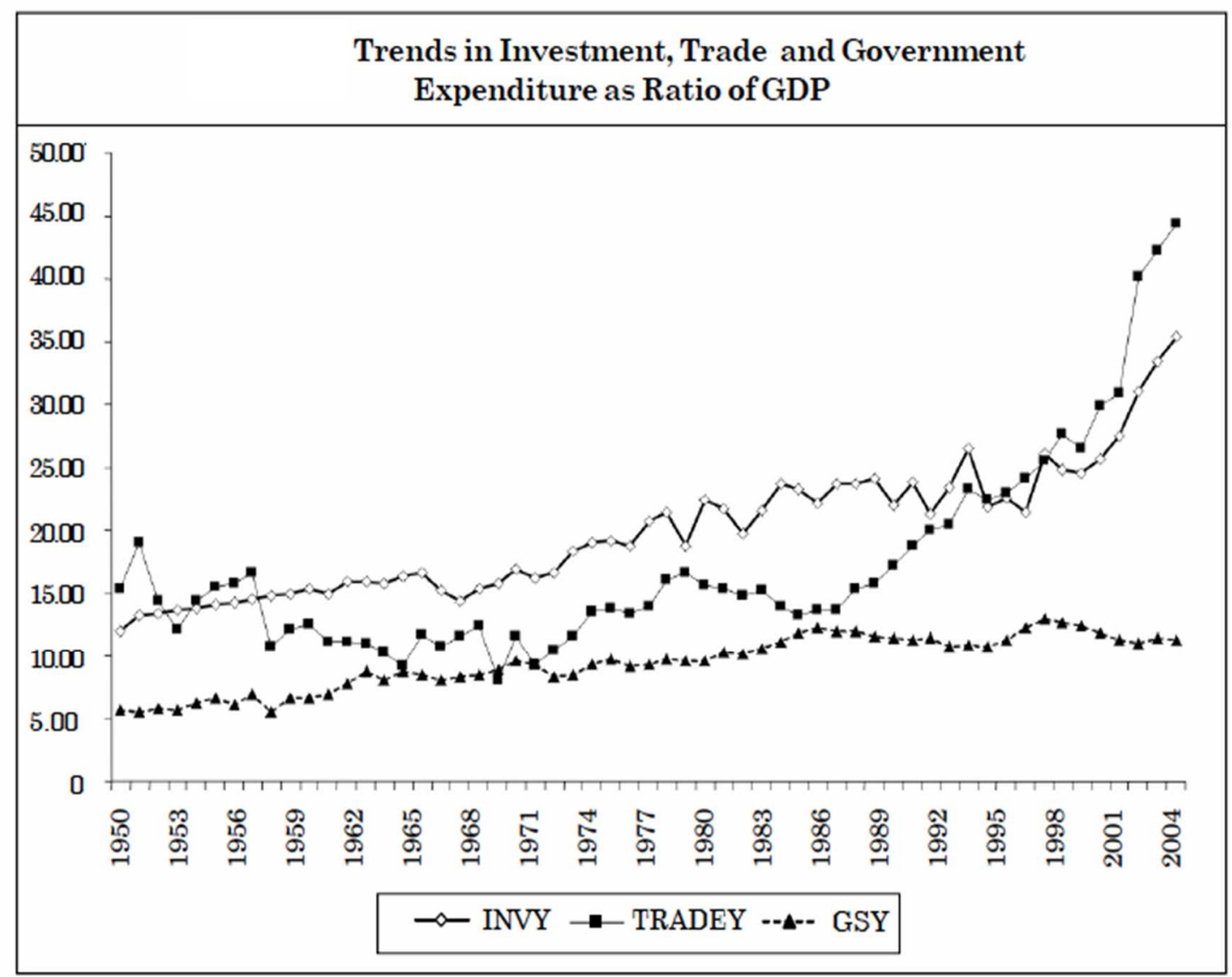

Figure 1. Investment, trade and government expenditure as ratio of GDP 1950-2004. Source: R. K. Dash \& C. Sharma, 2008, The IUP Journal of Public Finance, 6(3), p. 63.

Figure 1 shows the trend lines and it is clear that there is a steady increase in trade, investment and government expenditure, although trade and investment ratio of GDP has increased at a much higher rate than the government expenditure. The investment and trade ratio of GDP were 15 and 10 respectively in 1950 and this had increased close to $35 \%$ and $45 \%$ respectively.

Similarly, the positive impact of government expenditure on per-capita real income can be seen in Figure 2, which shows a positive relationship between the government expenditure and per-capita real income. In Figure 2 one can see as to how the 
government expenditure increased simultaneously with the real per-capita income. The real per-capita income ratio to GDP was 3\% during 1950 with a government expenditure around 8,000 crore rupees. The per-capita income has increased to close to $12 \%$ during the mid-2006 along with government expenditure which has increased to 16,000 crore rupees during the same period.

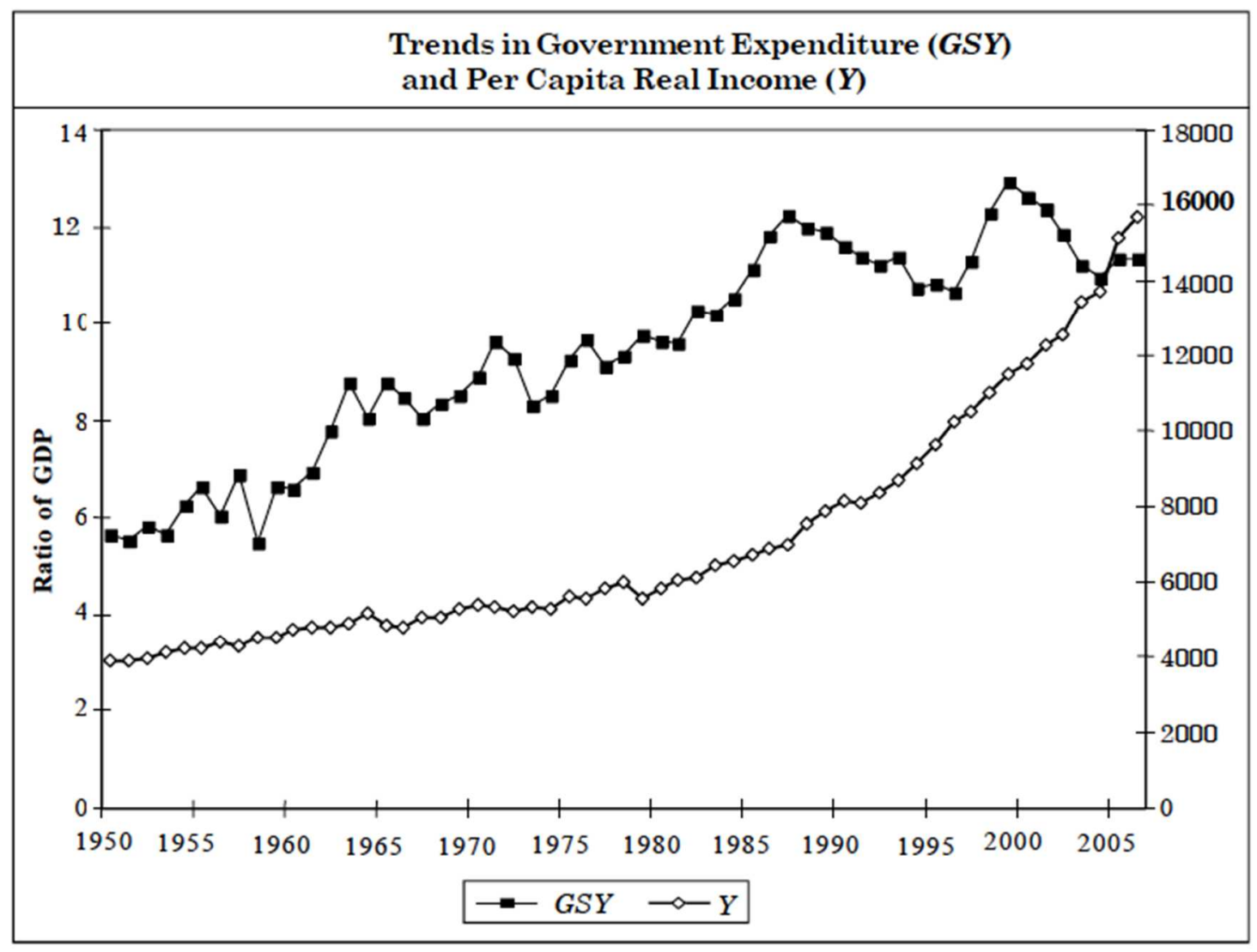

Figure 2. Trends in government expenditure and per-capita real income in India (19502005). Source: R. K. Dash \& C. Sharma, 2008, The IUP Journal of Public Finance, 6(3), p. 64.

Viswanath, Reddy, and Pandit (2009) examined the relationship between human capital and economic growth in India. The study was based on the inter-state data during 1995-1996 to 1998-1999. Using the aggregate production function, Viswanath et al. 
concluded that both human capital along with physical capital determine GDP growth rate in India. However, human capital is more crucial and statistically more significant than the physical capital in determining the net state domestic product across the states of India.

Analyzing the question, whether publicly supplied infrastructure is a significant determinant of regional economic growth in India, Lall (2007) argued investment on developing infrastructures will have significant impact on economic growth of states in India through benefits generated from such investments on infrastructure.

Similarly, Singhal, Grame, and Nguyen (2011) emphasized the importance of infrastructure for a developing country like India and the impact of infrastructure on economic growth. Furthermore, Singhal et al. argued that infrastructure development is a strong incentive for institutional investors due to the infrastructure's influence on economic growth and commercial property markets.

Addressing the issue of economic growth disparities among the states in India, Purfield (2006) explored questions such as are there disparities in economic growth among the states of India since 1990s, and, if so, whether economic policies at the state level have any impact on its economic growth. Analyzing these questions, Purfield opined that the income gaps between states are widening. Richer states are able to reduce poverty levels faster than poorer states. Furthermore, the capital and labor flow does not address the imbalances in the level of income and economic activity across states. Purfield concluded that state-level economic policies do impact its economic growth. 
Further, infrastructure development and diversification of the economic growth strategies play a crucial role in acceleration of the economic growth at the state level in India.

Purfield's (2006) analysis

presents evidence that state-level policies are a key factor influencing the pattern of economic growth across Indian states. Greater private sector investment, smaller government, and better state-level institutions . . . . are found to be positively associated with growth performance .... The historical structure of economic activity in a state also appears to matter for a state's subsequent growth performance .... states can impact their relative growth performance and accelerate convergence through their policy choices. (p. 21)

J. Mallick (2013), through his analysis of public expenditure by type (i.e., revenue and capital), and nature of public expenditure (i.e., investment and non-investment expenditures), argued that more balanced economic growth among the states of India is possible through proper allocation of resources in the form of expenditure, investment and development of infrastructure.

T. Singh $(2003,2008,2010)$ discussed the impact of services sector on the economic growth of India. T. Singh argued that the service sector has both direct and indirect effect on economic growth. Furthermore, Singh opined that continuous growth of the service sector is essential to cushion the burden of lack of growth in other sectors of the economy such as the manufacture and agriculture sectors and contribute to overall economic growth.

Priya and Kumar (2012) analyzed the impact of the service sector on India's economic growth. They have the belief that the liberalization of the regulatory framework has led to tremendous growth of service sector in India. Further, according to 2009-2010 estimates, service sector has contributed to $57 \%$ of the total India's GDP share. This percentage is an increase from 30\% share of GDP that the service sector provided during 
1950-1951. Concurrently, Sharma and Sharma (2007) analyzed the increased share of the service sector in GDP of India's economy. Sharma and Sharma presented the popular debate of how structural change occurs when an economy progresses from a developing to developed country through economic growth, that is, the relative increase of share of the industrial and service sectors over the agricultural sector in overall GDP. However, they argued that such a path has not been occurring in India. The share of the agriculture sector toward GDP has not declined and service sector has failed to generate more employment opportunities as it happened in other country's path toward developed country status.

Table 1 depicts the steady increase of contribution of service sector toward total GDP composition of India from 30\% in 1950-1951 to 57\% in 2009-2010 vis-a-vis other sectors of the economy, namely, agriculture and industry. Table 1 reiterates the growing importance and steady rise of service sector contribution to GDP growth in India.

Table 1

Percentage of Sector-Wise Composition of GDP in India (1950-2010)

Contribution of Service Sector towards Indian Economy

\begin{tabular}{cccc}
\hline Year & Agriculture \% & Industry \% & Services \% \\
\hline $1950-51$ & 55 & 15 & 30 \\
\hline $1960-61$ & 51 & 19 & 30 \\
\hline $1970-71$ & 44 & 23 & 33 \\
\hline $1980-81$ & 38 & 24 & 38 \\
\hline $1990-91$ & 31 & 26 & 43 \\
\hline $2000-01$ & 24 & 20 & 56 \\
\hline $2004-05$ & 20 & 20 & 60 \\
\hline $2009-10$ & 15 & 28 & 57 \\
\hline
\end{tabular}

Source: Priya, L \& Kumar, S (2012), p-629. 
One of the factors for the rise of the contribution of service sector in Indian economy was the change of trade policy and liberalization reforms which had started in full-fledged beginning 1990s. Ramakrishna (2011) has the belief that new trade policy adopted by India in early part of $21^{\text {st }}$ century has contributed to positive economic growth. The new trade policy of India with a twin objective of doubling India's share in global trade and to act as an instrument of economic development adopts the strategy that is more liberal, transparent, lowering the transaction costs and making India the global destination for goods and services. Ramakrishna concluded that trade liberalization in the form of new trade policy adopted by India played a positive role in influencing the economic growth of India.

Analyzing the accelerated economic growth in India since 1990s, Kohli (2007) argued that India's economic growth can be attributed not necessarily to the liberalization reforms post 1991 but to the pro-business growth strategy adopted by the Indian states. Accordingly, Kohli attempted to answer the question: Has India's growth acceleration resulted from the state's embrace of neoliberal policies, or from some more complex but identifiable pattern of state intervention? By examining the politics of economic growth through 1980s and 1990s, Kohli argued that the

. . a acceleration of economic growth in India was more a function of the probusiness tilt of the Indian state and less a result of the post-1991 economic liberalization. To support this argument (there are) two types of evidence: first, growth acceleration around 1980 coincided with the striking, but less-noticed shift in the state's economic role initiated by Indira Gandhi; and second, the aggregate economic performance since liberalization, especially industrial growth, did not improve during the 1980s. (Kohli, 2007, p. 111) 
Table 2 indicates that there is a steady increase in the growth rate across the sector. Further, the gross investment rate had an increase from $13 \%$ in 1950 to $22.5 \%$ in 2004 indicating that gross investment rate has almost doubled since 1950.

Table 2

Sector-Wise Growth Rate and Gross Investment in India during (1950-2004)

\begin{tabular}{|l|l|l|l|l|l|}
\hline & $1950-1964$ & $1965-1979$ & $1980-1990$ & $1991-2004$ & $1980-2004$ \\
\hline GDP growth & 3.7 & 2.9 & 5.8 & 5.6 & 5.7 \\
\hline Industrial growth & 7.4 & 3.8 & 6.5 & 5.8 & 6.1 \\
\hline Agricultural growth & 3.1 & 2.3 & 3.9 & 3.0 & 3.4 \\
\hline Gross investment/GDP & 13 & 18 & 22.8 & 22.3 & 22.5 \\
\hline
\end{tabular}

Basic growth data, 1950-2004 (all figures in percentage per annum). Source: A. Kohli, 2007, Studies in Comparative International Development, 42.

Thus, the above literature on economic growth studies has shown scholars using various economic and non-economic parameters that contribute to economic growth of India. The empirical studies have shown that economic factors such as capital, investment, trade have all shown to influence economic growth in India. Also, the noneconomic factors such as government expenditure, human capital and state policies have also contributed to economic growth in India. But there are relative gaps in the literature on economic studies in India in terms of analyzing the efficiency of government vis-a-vis resource extraction and resource management (physical, human and other form of capital). The current study attempts to fill this gap by looking at the Relative Political Capacity (RPC), which is a measure of efficiency of government in resource extraction and resource management and see how it influences the economic growth in India. 
The early literature on measuring the political capacity of a government is found in the works of Musgrave (1983), Bahl (1971) and Lotz and Morse (1967) who initially attempted to use the taxation power of the governments and how it can used to measure the capability of the government. Further exploration on measuring the resource extraction capabilities of the government as a measure was done by Organski and Kugler (1980) whose study explored whether political elites within a government have the necessary tools to achieve the results. They questioned, “... Do elites have the tools to extract resources from their societies, aggregate the many contributions each citizen makes into national pools, and use them for national puposes? (Organski and Kugler, 1980, p.70).

The conceptualization of RPC for this study is based on the Arbertman and Kugler (1997) and Arbetman-Rabinowitz, Kugler, Abdollahian, Kang, Tammen (Kugler and Tammen (eds): 2012) who argued that RPC reflects the ability of government to extract economic resources and use those resources towards achieving and accomplishing policy goals. Subsequently, Kugler and Tammen (2012) offers a three pronged approach to measuring RPC, namely, Relative Political Extraction (RPE), Relative Political Reach (RPR) and Relative Political Allocation (RPA). Each of these components reflect the ability of government in extracting the resources (RPE); mobilizing its population (RPR) and allocating the resources efficiently (RPA) towards achieving the policy goals.

The measures of RPC are independent of regime type and developed as a political measure for comparative analysis of capabilities of governments across the world at various points in time. A detailed discussion on the parameter and composition of each of 
these RPC components will be dealt in the next chapter while discussing the methodology.

For the purpose of this dissertation, RPE is used as an indicator of RPC. RPC was used along with other parameter within a model to analyze the economic growth. One of the parameters of the model is the gender wage gap. Accordingly, the next section of chapter discusses some of the existing literature on gender wage gap.

\section{Gender Wage Gap and Economic Growth}

In the field of sociology, the literature has dealt in depth about the gender wage gap and its effect on the sociocultural fabric of a society (Menon \& Rodgers, 2009; Olsen \& Sexton, 1996; Polachek, 1987; Robinson, 1998; Shenhav \& Haberfeld, 1992; Terrell, 1992; Weichselbaumer \& Winter-Ebmer, 2005). Further literature on gender wage gap covers various socioeconomic perspectives on gender wage gap (Chamarbagwala, 2006; Grybaite, 2006; Huang, 1999; Mincer, 1958; Weichselbaumer \& Winter-Ebmer, 2005). There are three main theories that explain the gender wage gap in labor markets. They are human capital theory, labor market segmentation theory (also called Occupational Segregation model), and labor market discrimination theory (gender discrimination theory). Human capital theory emphasizes the effects of education, training, and work experience on individual labor productivity, pointing to a direct link between the level of education, length of service, and experience on the one hand, and productivity on the other (Mincer, 1958).

Segmentation theory subdivides the labor market into primary and secondary sectors, with jobs in the two sectors totally different in terms of pay, security, 
advancement opportunities and working conditions. This segmentation of the labor market reduces wages in female occupations through an overcrowding effect: i.e., with large numbers of women forced into a narrow range of jobs, wages for those jobs abound to be lower than they would otherwise be. Gender discrimination theory seeks to identify non-labor market factors to account for the persistence of wage differentials (Huang, 1999, pp. 361-362). With this theoretical background, the following section explores various studies that are situated within these three theoretical contexts of gender wage gap.

The empirical studies on gender wage gap in relation to Taiwan have shown that access to higher education for women would narrow the gender wage gap (Huang, 1999) By analyzing the interactive effect of gender, high level of education, and years of experience in Taiwan, Huang (1999) argued that higher education along with more years of experience among women can narrow the gender wage differentials.

Terrell (1992) argued that occupational segregation is the cause of wage differential between the male and female earnings. Terrell has the belief that, occupational segregation occurs due to wage discrimination in the employment market and in some cases such discrimination starts earlier at the education level.

Wellington (1994) analyzed the wage gap between the white male and white female employees from 1976 to 1985 using human capital model. Wellington has the belief that most of the wage differential between genders can be attributed to the differences in the years of full time employment and year of unemployment after entering the labor force. Wellington uses the data on employment history and training on-the-job 
to arrive at the above conclusions. The results of the analysis showed that, training and experience acquired during the job had greater impact on the gender wage differential than the overall qualification acquired by men and women in the form of education. In other words, irrespective of the educational qualification, it is the on-job training and experience that mattered most in determining wages and accordingly, men relatively have better on-job training and experience than women.

Olson and Sexton (1996) also emphasized the role of on-the-job training in gender wage differentials. They found,

that previously trained workers exhibit larger cumulative wage gains during their current training. Thus, a substantial portion of the gender wage gap results from the fact that women have little prior training relative to men. Second, a significant amount of the observed male/female wage differential is explained by less female acquisition of current training. Gender differences in workplace promotion and training help explain why women accumulated less training than men. (Olsen \& Sexton, 1996, p. 59)

They argue that such differences in the on-the-job training between male and female workers have reduced over the years contributing to the relative lesser gender gap between male and female wages.

Polachek (1987) attempted to explore whether occupational segregation can explain the gender wage differentials. The occupational segregation hypothesis claims that,

certain occupations are set aside predominantly for women, although men are free to pursue the occupation of their choice. The result is that women are forced into menial occupations, thereby increasing the supply of female workers in female jobs and depressing women's wages. (Polachek, 1987, p. 49)

Based on the occupational segregation hypothesis, Polachek attempted to analyze whether occupational segregation has any impact on the gender wage differences in 
earnings. As opposed to the occupational segregation hypothesis, the human capital model of neoclassical theory suggestions that, "ceteris paribus, those persons with the highest levels of labor force intermittency will select occupations with the lowest penalties for intermittency-i.e., will select occupations exhibiting the highest, flattest age-earnings profiles and the lowest atrophy rates" (p. 60). Based on the analysis, Polachek concluded that findings of the statistical study confirm the human capital model in explaining the gender wage gap at the work place.

Oostendorp (2009) investigated the role of globalization on the gender wage gap. The conclusion is that globalization has helped in reducing gender wage gap only in the developed/richer countries. With regard to poorer countries, they have to reach certain level of development before realizing the effect of globalization on gender wage gaps. Oostendorp guessed that such minimal effect of globalization in the form of trade and Foreign Direct Investment (FDI) on the gender wage gap in poorer countries might be due to measurement error, lack of bigger sample size and quality data.

Tam (1996) argued that in Taiwan, common theoretical explanations such as labor force experience, differences in schooling, selective bias and statistical discrimination do not explain the wage gap. On the contrary,

a larger part of the gender wage gap appears to have resulted from gender differences in family role constraints. As a result, women's progress in labor force participation and work experience is unlikely to translate into any sharp reduction in the gender wage gap. Large reductions in the gender wage gap in Taiwan apparently require a more equal sharing of family responsibilities by both men and women. (Tam, 1996, p. 831)

This section has explored the theoretical background to gender wage gap. It is clear from the above that most of the studies on gender wage gap situate within the three 
theoretical contexts of gender wage gap, namely, human capital theory, labor market segmentation theory, and gender discrimination theory. With this theoretical background, how are gender wage gaps measured. The next section attempts to explore some of the literature on the measurement of gender wage gap.

\section{Literature on Measuring Gender Wage Gap}

Regarding literature on measurement of gender wage gap, Weichselbaumer and Winter-Ebmer (2005) surveyed various studies that dealt with measurement of gender wage gap. They investigated 260 published papers covering the time period of 1960 -

1990s. Their analysis results indicated:

Data restrictions have the biggest impact on the resulting gender wage gap ... Frequently, researchers do not have hourly wages or actual experience at their disposal, let alone a complete record of human capital characteristics, like training on-the-job or job tenure with the actual employer. Missing or imprecise data on these human capital factors can result in serious biases in the calculation of the discrimination component ... . Furthermore our analysis allowed us to investigate the gender wage gap over time. From the 1960s to the 1990s, raw wage differentials worldwide have fallen substantially from around $65 \%$ to only $30 \%$. The bull of this decline, however, must be attributed to better labor market endowments of females which came about by better education, training, and work attachment. (Weichselbaumer \& Winter-Ebmer, 2005, pp. 507-508)

Similar studies on measurement of gender wage gap were conducted by

Haberfeld, Moshe, and Audrey (1998). They analyzed and estimated gender-based wage differentials using the Hierarchical Linear Model (HLM). The rationale for using the HLM is that,

it treats each occupation as a separate labor market, whereas the conventional model assumes that there is only one labor market. As a result, the HLM enables us to estimate the extent to which individual- and occupational-level characteristics explain the earnings gap between the two gender groups .... Second, the HLM avoids the serious problem of correlated individual disturbances. The inclusion of occupation-level variables in the conventional 
models causes the disturbances for individuals in the same occupation to be correlated. (Haberfeld, Moshe, \& Audrey, 1998, pp. 97-98)

Applying the HLM method to the Israeli census data of 1983, Haberfeld et al.

(1998) concluded that at the individual level gender has a significant effect on the

earnings. At the occupational-level, jobs dominated by the women pay less than the one

dominated by men.

socio-economic status of an occupation, size, and the level of complexity of dealing with people are mostly responsible for variations in the gender-earnings gap across occupations. Gender inequality tends to be lower in high status and in large size occupations, and tends to be more pronounced in occupations characterized by greater complexity of work with peoples. It might be that highstatus and large-size occupations are highly visible and more regulated, thus making differential treatment of workers within them more difficult. On the other hand, occupations that require a high level complexity with people could enable a lot of discretion in defining and measuring performance levels. Such discretion might lead to a differential treatment of men and women. (Shenhav \&Habefeld as cited in Haberfeld et al., 1998, pp.108-109)

Haberfeld et al. concluded that analysis of Israeli data shows that there is no effect of gender wage gap both at the occupational level and at the individual income level.

Jarrell and Stanley (2004) revisited their meta-regression analysis approach in examining various studies on measuring gender wage discrimination. In this article Jarrell and Stanley tested the adequacy of their meta-analysis in synthesizing the empirical labor research. The conclusion of meta-analysis shows that, there is a need for using the correct estimate of calculating gender wage gap, which is, using hourly wages over annual or weekly wage estimation. Further, the accounting of bias effect of researchers' gender in his or her selection of data has shown that there is indeed an improvement in the wage differential situation among genders and also the overall research on gender inequality from an economic perspective. 
Robinson (1998) explored differences in occupational earnings of men and women using various approaches to measuring wages. Robinson applied three main measurements of pay to analyze the pay differentials. (a) Pay scales or job rates, which, calculates the actual pay of male and female employees of a job; (b) Average wage or salary rates, which includes basic pay and the regular perks that come with a particular job; and (c) Average earnings, that is,

earnings as the remuneration in cash and kind paid to employees, as a rule at regular intervals, for time worked or work done, together with remuneration for time not worked, such as for annual vacation, other paid leave or holidays . . . (Robinson, 1998, p. 13)

With the above measurement approaches and cross country comparison, Robinson concluded that there are significant wage differences between male and female workers across comparable categories.

Gender wage gap studies in India. This sub section of the chapter narrates some of the studies on gender wage gap within the context of India. Mahajan and Bharat (2012) discussed the variation in wages in relation to gender within India. They analyzed the difference in the labor supply between male and female labor supply in the agriculture sector, which is due to the tradition of restriction of female labor in the agriculture sector. Furthermore, Mahajan and Bharat have the belief that there is an over reliance of male labor supply on the agriculture sector due to unavailability of employment opportunities in non-farm sectors. Both these factors determine the wage difference between male labor and female labor force in India.

Boserup argued that the "variation in gender wage differential across states is because of variation in female labor supply ... . [variation in female labor force] revolves 
around the cultural restrictions on women's participation in work and the variation in this norm across India” (Mahajan K and Bharat R, 2012, p. 3). Further Boserup had come up with a hypothesis that has been proven correct. Boserup's hypothesis states

Female labor supply has sizeable effects on female wages but not so much on male wages. An immediate implication of the results is the gender wage gap might be a misleading indicator of the "economic freedom" enjoyed by women. The gender gap in the labor force participation is important as well. (Boserup as cited in Mahajan \& Bharat, 2012, p. 27)

Bhaumik and Chakrabarty (2008) argued that the gender wage gap in India has reduced post 1990s economic reforms. Examining the two data points for urban sectors for 1987 and 1999, Bhaumik and Manish have the belief that such narrowing of the gender wage gap in India over the years can be attributed to the sudden increase in the returns to the labor market experience of women. In other words, changes in the educational endowments of women have contributed toward the gender wage gap reduction. Such gender wage gap reduction had been to the tune of $35.72 \%$ in 1987 to 5.29\% in 1999 (Bhaumik \& Chakrabarty, 2008, p. 602). Further Bhaumik and Manish concluded that, post-1990 economic reforms have led to a job increase in service sector of India. The result is equal opportunity to work for both men and women. Service sector jobs such as software and call centers have reduced gender wage gap to certain extent by providing access to highly educated, experienced workforce irrespective of gender. Chamarbagwala (2006) asked what is causing the wage gap among the skilled labor force and at the same time narrowing the gender wage gap following the 1990s economic reforms. The answer lies in the demand for skilled labor force that came along with the liberalization policies and up gradation of the manufacture sector. This has resulted in the benefitting skilled men compared to skilled women. However, in service 
sector, outsourcing of jobs has been helpful to both men and women by creating a demand for any college graduates.

Menon and Rodgers (2009) argued that increasing competition and international trade is associated with the large gender wage gap in India's manufacturing industries. Even though neoliberal theory argues that international trade reduces gender wage gap, the case of India seems to prove otherwise. The neoliberal argument is that competition reduces gender wage gap because discrimination is expensive for the market economy.

However, in case of India, Menon and Rodgers (2009) concluded that

Rather than competition from international trade putting pressure on firms to eliminate costly discrimination against women, pressure to cut costs due to international competition are hurting women's relative pay in the manufacturing sector of India. Lack of enforcement of labor standards that prohibit sex-based discrimination, combined with employer and union practices that favor male workers, leaves women with less bargaining power and limited gains compared to men. (p. 976)

The above sections of the chapter explored the various literature in field of economic growth, empirical studies on economic growth, studies on economic growth in India and literature on gender wage gap. Further literature on the theories of economic growth had analyzed various studies that have situated within the exogenous and endogenous models. Various empirical studies on economic growth have shown how economic and non-economic factors affect growth in an economy. Subsequently, literature on gender wage gap situates itself within the three theoretical frameworks of human capital theory, labor market segmentation theory, and gender discrimination theory.

The current research study situating within the endogenous growth model attempts to explore determinants of economic growth using the parameter of government 
efficiency (RPC) and gender wage gap within the context of India. From the above literature review it is clear that there is a lack of sufficient literature with regard to endogenous models of economic growth in Indian context. The current study attempts to fill such a gap by analyzing the effect of government efficiency and gender wage gap on India's economic growth. Subsequently, the study also adds to the existing body of literature in the field of gender wage gap theory, namely, on human capital theory and gender discrimination theory by looking at the education attainment across gender and wage discrimination in labor markets that are not necessarily related to one particular occupation.

The model of analysis used in the next chapter is based on Seguino's (2000a, 2000b) model. Seguino reasoned that increasing the gender wage gap is helpful for economic growth by driving down the cost of production. The argument is that by paying the female labor force low wage, an economy can take advantage of low-cost labor force toward increasing economic growth. The current research study used Seguino's model to make the opposite argument, which is, whether increasing the gender wage gap effects economic growth by depriving skilled labor force from entering the labor market and, in turn, labor productivity and growth. Accordingly, the model that is presented in the next chapter is whether economic growth as a dependent variable is affected by a given level of independent variables such as capital stock, human capital, labor force (male and female), RPE and gender wage gap. A detail discussion of model specification, variable definition and variable measurement is done in Chapter Three. Accordingly, we turn to the next chapter that deals with model specification of how this 
research study is going to encompass the above discussed parameter into the model of analysis. 


\section{Chapter 3: Research Methodology}

The literature review in the previous chapter suggested the role of various economic and non-economic factors on economic growth of a country (Comeau, 2003; Feng, 1995; Mankiw et al., 1992; Sala-i-Martin, 1994; Solow, 1956). Additional studies reviewed various theories on gender wage gap and empirical studies on gender wage gap. (Bhaumik \& Chakrabarty, 2008; Huang, 1999; Mahajan \& Bharat, 2012) In this context, the current chapter proposes models that analyze the impact of political performance and the gender-wage gap on economic growth.

The research model is derived from the Seguino's (2000a, 2000b) model, which established a positive relationship between gender wage gap and economic growth. Seguino's argument is that gender wage gap has significant positive impact on economic growth by keeping the cost of production low. The current research study attempts to question this argument through extrapolating this model in the Indian context. It differs from Seguino's model on the following counts: First, it adds political capacity measured in terms of RPE to the model; Second, the human capital factor is added into the model; Third, it analyzes the independent effect of political performance (measured in terms of political extraction) and the gender wage gap on economic growth. Fourth, while Seguino's study looked at the manufacturing sector and impact of wage difference in terms of competitiveness of products, this study examines wage differentials across the various sectors of the economy. In other words, the study looks at wage differentials at all the sectors of the economy, namely, agriculture, manufacturing and service sectors. 
The research study uses a time series regression method. There are three models that are tested here. Since one of the primary focuses of the research is to examine the effect of gender wage gap and political capacity on economic growth, initial models are examined excluding either of these variables and the final model was run with both the variables included. The rationale for such an attempt is to examine how the variables fare in the models in the absence of the other variable and in the presence of each other.

Accordingly, first model examines the effect of independent variables such as capital stock, economically active population (labor force), human capital, and RPE on dependent variable of GDP growth rate change. Similarly, Model II looks at all the independent variables of the Model I except it replaces independent variable of RPE with another variable of gender wage gap. Model III analyzes all the independent variables of capital stock, economically active population (labor force), human capital along with both the independent variables of gender wage gap and RPE together within a model. The rationale for removing and replacing the independent variable of RPE and gender wage gap is to see how each of these variables behave independently of each other and together within a model.

\section{Definition and Measurement of Variable Terms}

The dependent variable discussed in the model is economic growth. The term Economic Growth used in this study refers to the GDP of the government in India. GDP at the rate of current account refers to total volume of goods and services that a national government produces in a given period of time. 
One of the independent variables used in the model is RPE. The term RPE is broadly defined as capacity of a government to extract resources from its citizens efficiently. RPE is part of a RPC defined as "the ability of governments to reach their population, to extract economic resources from that population and to allocate those resources to secure the long term survival of the political structure" (Kugler \& Tammen, 2012, p. 7). RPC measures the political performance relative to the respective governments across nations, time and societies. ${ }^{1}$

Figure 3 summarizes the RPE measure for India over the study period considered. Figure 3 shows that the RPE scores have been fluctuating over the year. However, the overall scores have been declining from 1.2 in 1970 to 1.0 in 2010 . Figure 3 provides a background in understanding economic growth in India over the years with a given level of RPE scores.

\footnotetext{
1 The formula for calculating RPC can be stated as below:

Political Capacity $=$ Political Reach * Political Extraction * Political Allocation 


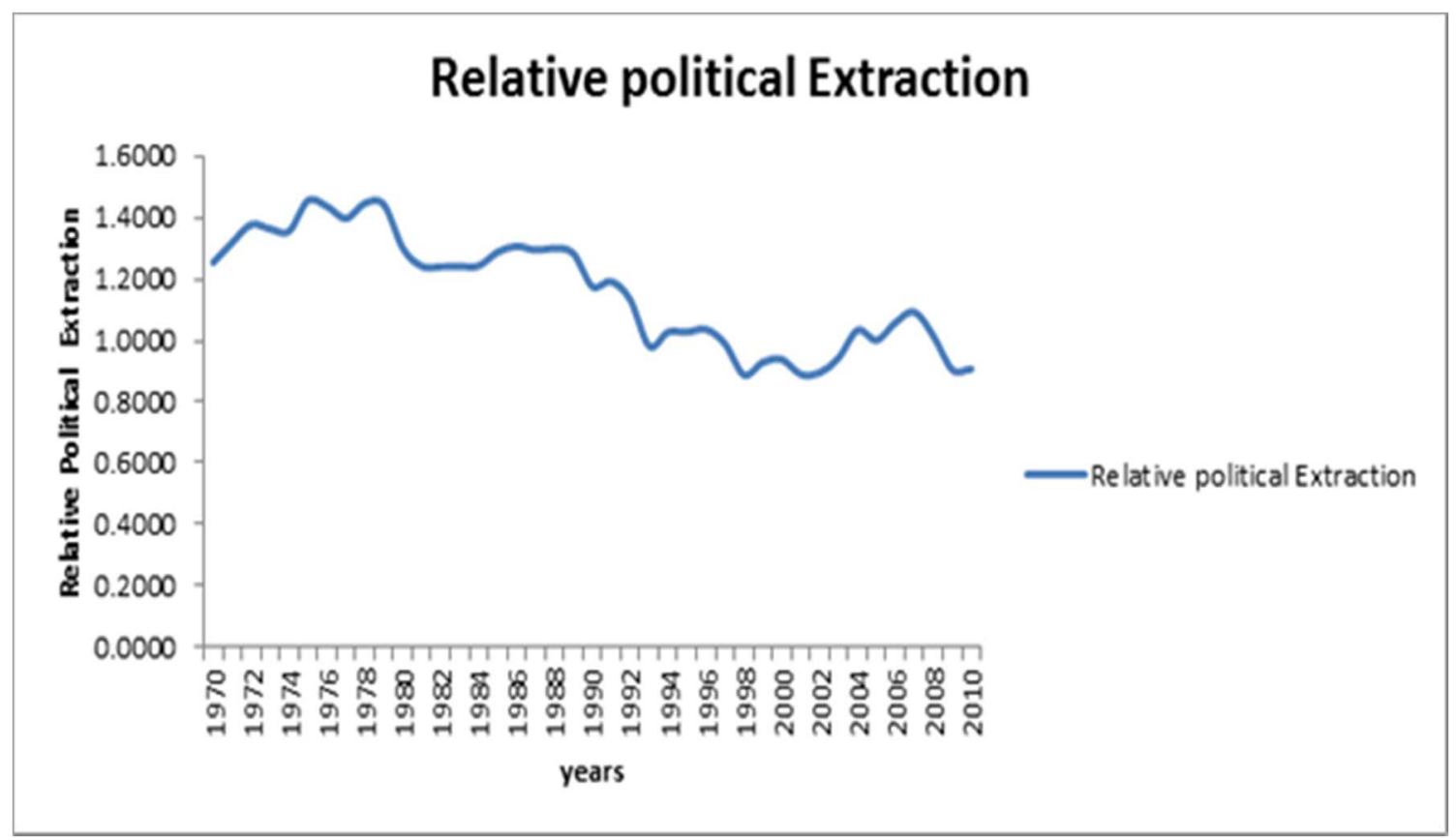

Figure 3. Level of RPE in India (1970-2010). Source: J. Kugler and R. L. Tammen (Eds.), 2012, The Performance of Nations. Data Source: Trans Research Consortium (http://www.transresearchconsortium.com/).

RPE is one of the components of political capacity. RPE is the measure of a government's efficiency in the form of resource extraction. The RPE score is the outcome of the actual tax revenue extracted by a government over the predicted tax revenue with a given level of economic development. The tax revenue is measured over time and is dependent on the outcome of the resources through mining, agriculture and exports of a government.

Another independent variable used in the model is the parameter of capital stock. Capital stock of a country is broadly referred to as that part of national wealth that is reproducible; it consists of all resources, which, contribute to the production of goods and services. 
The changing relationship between output and capital stock is an important aspect of the study of changes in productive efficiency in the various industries of a developing economy. Firm estimates of capital stock enhance the ability to associate capital formation with economic growth and to project future production possibilities, thereby leading to formulation of policies designed to achieve the desired economic objectives. These also provide a firm basis for estimating capital consumption needed to arrive at the estimates of various macro-economic aggregates on net basis. (National Accounts Statistics Sources and Methods, 1989, Ch-22, p.1)

Figure 4 indicates the substantial growth of capital stock in India at national level government. The capital stock has increased nine fold from 1970 to 2010 . This shows that Indian government, at the national level, had a substantial amount in the form of capital stock to utilize on various plans and policies aimed at overall economic growth of the economy.

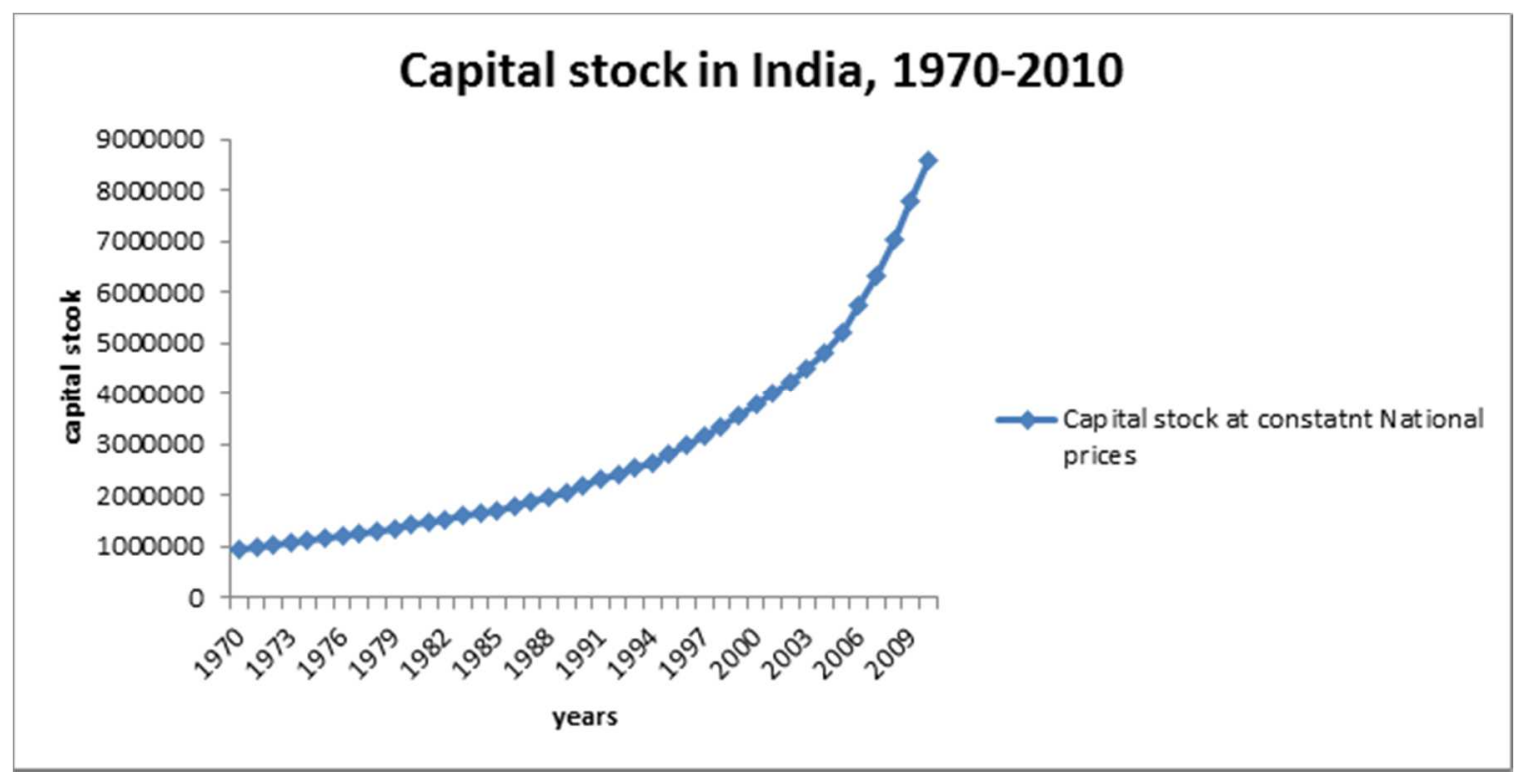

Figure 4. Capital stock in India (1970-2010). Source: ECONOMIC RESEARCH: Federal Reserve Bank of St.Louis (n.d.) 
One of the independent variables used in the model is human capital. "Human capital is the stock of skills that the labor force possesses" (Goldin, C. 2014, p. 1). In other words, human capital is defined as the population of the country (here India) who are above a certain age, skilled and employable. It has been argued that human capital accumulation requires institutions (both economic and political) that are enabling. Inefficient government will lead to human capital accumulation that is not optimal (Goldin, 2014). The growth rate of human capital $\mathrm{K}$ in the model is measured using average total years of educational attainment per person over 15 years of age, as well as average years of secondary education.

Figure 5 plots the human capital increase for India from 1970 to 2010 . Figure 5 indicates that there is a steady increase of human capital in India from around 500 points in 1970 to around 2,000 points in 2010. Based on the data that Figure 5 depicts, one can expect human capital in India to grow continuously in the following years. Further, Figure 5 also enables us to understand with a given level of human capital, what is the effect of such level of human capital on economic growth in India. 


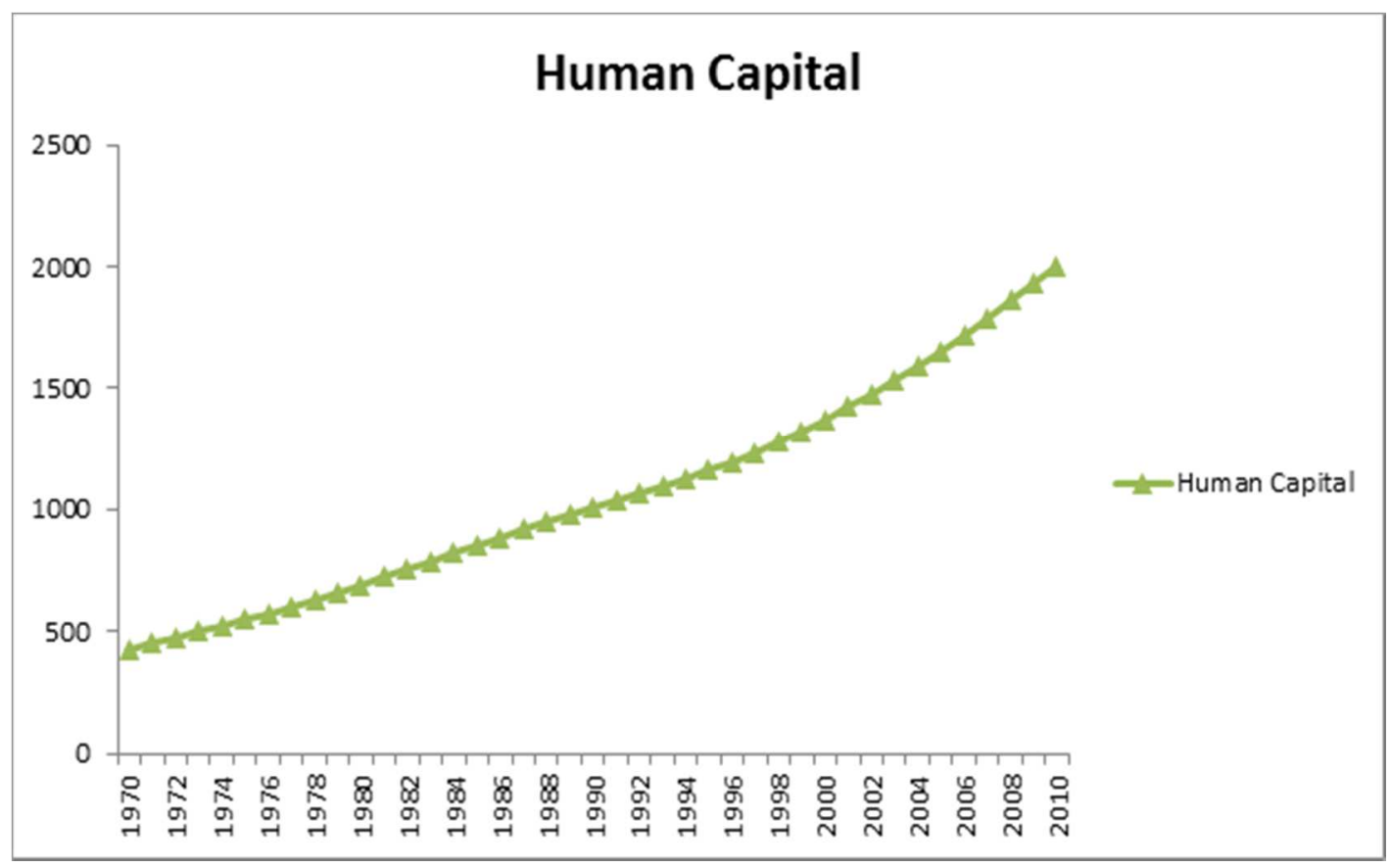

Figure 5. Human capital in India (1970-2010). Source: prepared using data from the thesis Human Capital and Economic Growth in India, Indonesia, and Japan: A quantitative analysis, 1890-2000, Bas van, L. (2007).

Labor Force is the combined labor force of female and male labor supply, and refers to both a male and female population over the age of 15 years who have certain skills to offer, can be used to produce goods and services, and who are employable.

Figure 6 indicates that the growth rate of economically active population has been constant around 0.50 points since 1970 to 2010. Figure 6 helps us understand, with a given level of economically active population, what the actual level of labor force participation is and how it affects the economic growth during the period of research study that is analyzed here. 


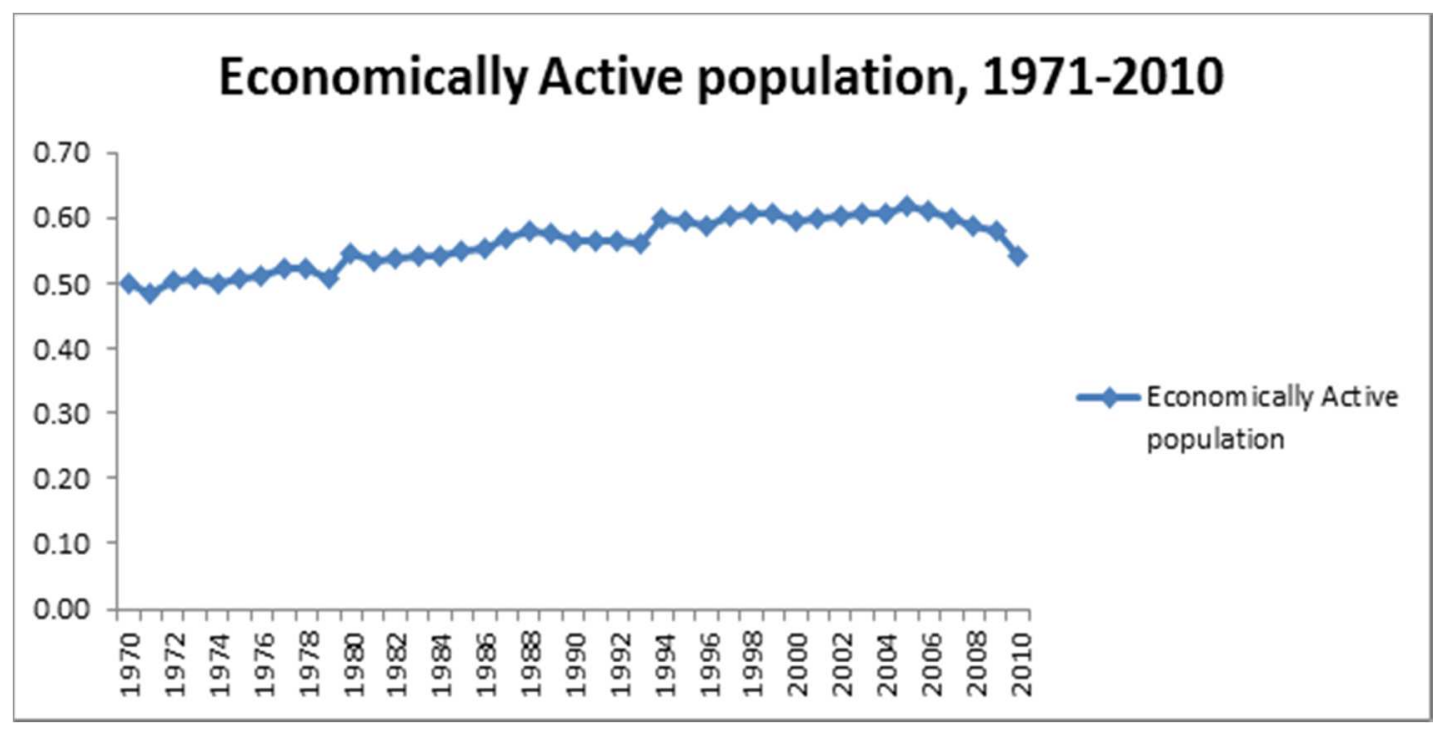

Figure 6. Potential labor force in India (1971-2010). Source: Estimation using data from India Labor Stats, NationMaster (n.d.)

Wages are the income earned by the labor using its productive capacity. The wage gap between the male and female labor force is known as gender wage gap. The gender wage gap used in the model refers to difference in the wages between the male and female labor force in India.

For calculating the gender wage gap, wages are proxied by consumption expenditure in all the models. Studies, especially those that are focused on India, have used consumption expenditure as proxies to assess the wages (Belser \& Uma, 2010; A. Singh, 2012; Srivastava \& Sanjay, 2010). The rationale for studies using such a proxy is that even though India has a minimum wage law established, in reality there are huge differences across the regions within India on prevailing wages. Hence, the current study used consumption expenditure proxied on wages so that it would provide for a better analysis and robustness of the models. 
Two measures of the gender wage gap borrowed from Seguino (2000a, 2000b) are being used. The first measure calculates the differences in consumption expenditure between male and female labor force. This can be represented as $\log \left(\mathrm{W}_{\mathrm{m}}\right)-\log \left(\mathrm{W}_{\mathrm{f}}\right)$ where $\mathrm{W}_{\mathrm{m}}$ and $\mathrm{W}_{\mathrm{f}}$ refers to male and female consumption expenditure respectively. However, the above criteria of measuring wage gap might result in differences in the labor productivity. In order to control for differences in labor productivity, a second measure of the wage gap is used. The second measure of the wage gap is calculated by taking into account women and men's secondary educational attainment. The measurement is as follows:

$$
\text { WGAP2 }=\log \left(\mathrm{W}_{\mathrm{m}} / \mathrm{SYRM}\right)-\log \left(\mathrm{W}_{\mathrm{f}} / \mathrm{SYRF}\right)
$$

Where SYRM and SYRF refers to the average years of secondary education per male and female over 15 years of age.

Based on the above measure of gender wage gap, the data are plotted on the graph over the period that is considered for the study. Figure 7 indicates that the gender wage gap has been narrowing from 0.13 in 1970 to 0.09 in 2010 indicating positive signs toward reduction of gender wage gap. However, there is still scope for improving the gender wage gap. The above table, as with the other parameters of the model of analysis will help in understanding how with a given level of gender wage gap over the years has its effect on economic growth. 


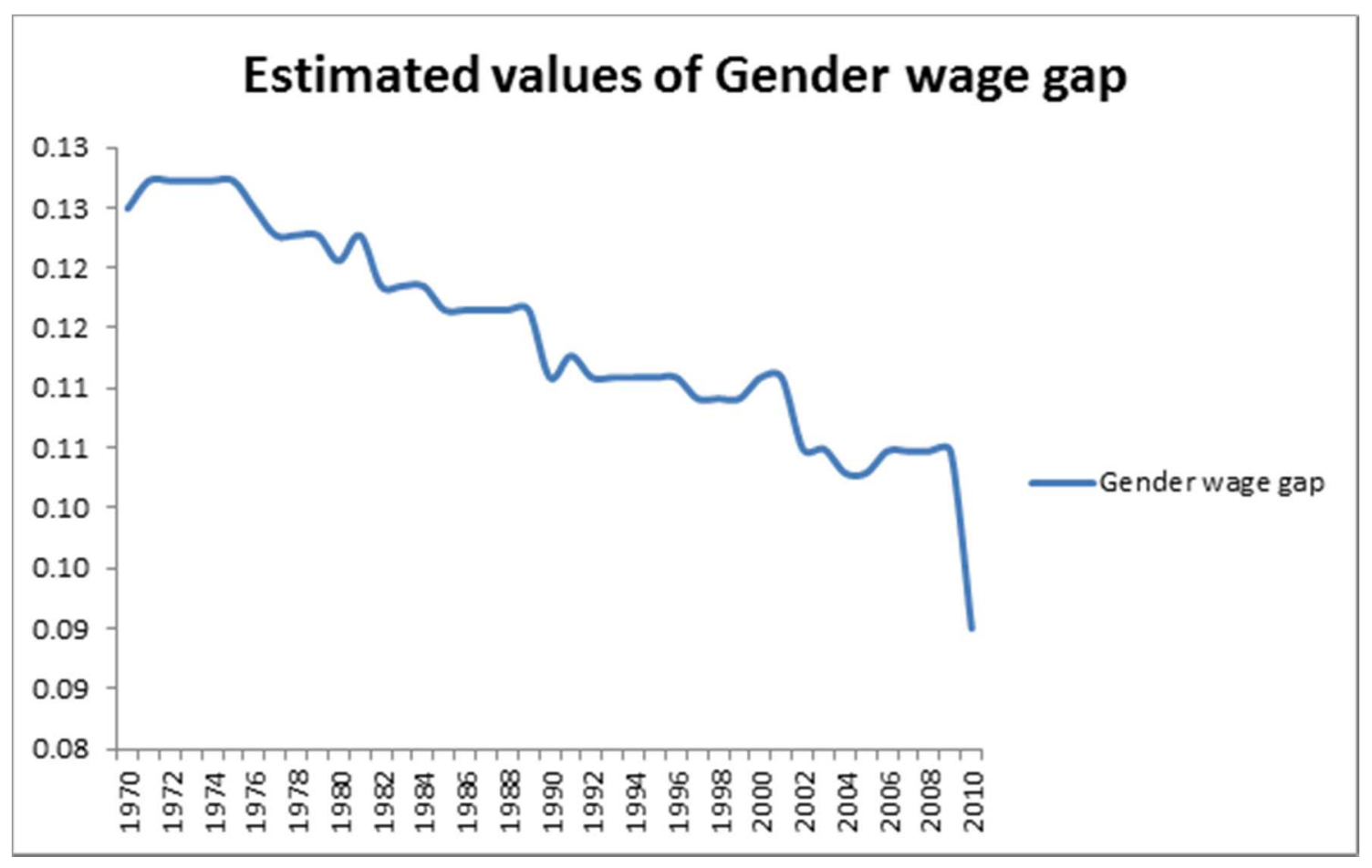

Figure 7. Gender wage gap in India (1970-2010). Source: Estimation using data from various annual reports Government of India, Ministry of Labour and Employment (n.d).

The sample size of the study includes data of all the variables used in the model at national level from 1970 to 2010 . The intended data are collected through secondary sources of databases such as the Trans National Consortium Database on Political Performance, national and provincial government of India, and the National Public Finance and Policy Institute websites. The macro level data on capital expenditure, capital stock and labor supply are obtained from Central Statistical Office of India, National Accounts Division and National Accounts and Statistics (Government of India, Ministry of Statistics and Programme Implementation, n.d.). Micro level data are obtained from National Sample Survey Organization, Handbook of Statistics on Economy (Reserve Bank of India, (n.d.)). 
The above paragraphs of this chapter summarize the models of analysis used to tackle the various research questions. The definitions and measurement of the variables in the models are also discussed along with the model specifications. A brief graphical representation of the variables in terms of related data were presented to provide a level of understanding where they stand in their individual capacity at the national level. How do these variables behave in a model? What would be the result of actual analysis of the model? The following chapter analyzes these questions. 


\section{Chapter 4: Economic Growth and Productivity: Analysis and Findings}

Indian economy under "license- permit-quota-raj” until 1990 was steeped in inefficiency at all levels (Riley \& Ravi, 2016). License-permit-quota-raj refers to particular type of regime dominated by regulations, price control and import restrictions. The motto under this regime was growth with equity rather than efficiency. This resulted in a lack of foreign competition and assured the market share had resulted inefficient use of both physical and human resources. Further, such inefficiency was also seen in the tax regime of the economy. Tax inefficiency can be seen in policies that were ineffective in resource extraction. Loopholes in the policies are used to evade taxes and India's political capacity was stagnant through these years.

The liberalization policy adopted by India post 1990s had unleashed the bottled up potential for economic growth and development. Subsequent reforms and policies adopted at the macroeconomic level have led to economic development in a positive direction (Bhaduri, 2005). One of the reforms of economic liberalization emphasized efficiency in all sectors of the economy leading to maximum utilization of resources both physical and human leading to positive economic growth. Further implementation of these reforms leading to positive results required an able government that will be able to carry out the policy objectives against opposing forces. In other words, a government with a better RPC. Following the works of Kenneth Organski and Marina Arbetman and Jacek Kugler (1997), the current study defined RPC as the ability of a government to carry out a given set of policy objectives against competing political groups with their own policy objectives and priorities. Applying these concepts to our current study, it 
implies the ability of government to efficiently extract both physical and human resources toward positive economic growth. The efficiency in physical resource extraction is measured and incorporated in the model analysis by the variable Relative Political Extraction (RPE) whereby, a particular score at a particular point in time depicts the level of efficiency of a government in resource extraction.

The ability of governments to extract resources from its population is the main tenet of the concept of political capacity.

Governments all require resources in order to enact policies. Taxation represents willingness on the part of the population (or enforcement ability on the part of the government) to transfer resources from the private individuals to the government. This resources transfer is the bridge between politics and money; taxation demonstrates an endorsement or at least acceptance of the government by the population. (Arbetman-Rabinowitz \& Johnson, 2007, p. 4)

In the context of economic growth, governments with a high level of extractive capacity are in better position to provide the necessary infrastructure and ensure stability for conducive economic growth environment.

Similarly, the efficient utilization of the human resources is also important in enhancing the economic growth. Harnessing the human capital effectively is one of the efficient ways of utilizing the available human resources. The rationale is higher human capital can be relatively more productive than low human capital. Further, high human capital represents a higher skill set leading to better productivity. Gender wage gap has been a serious hindrance in efficient utilization of human capital. The economic and sociocultural factors have been a negative influence with regard to human capital realizing its full potential. Economic factors such as wage gap between male and female workforce and sociocultural aspect of stereotypical gender role and unwritten societal 
norms have restricted women from entering the market and be a player in the economic growth process. The study recognizes the sociological impact of gender wage gap on women and their empowerment. However, the current research intends to concentrate on the economic factor represented by gender wage gap and analyze whether gender wage gap has any negative impact on economic growth.

Studies have shown that wage gap is prevalent across the sector in India (Jahnavi, R: 2106). According to Monster Salary Index (2016) during the year 2013, 2014 and 2015 the gender wage gap across the various sector in India is as follows: a) Legal and market consultancy, business activities $(24.20 \%)$; b) Information and communication technology (34\%); c) Health Care, care services, social work (26\%); d) Education, research (22\%); e) Financial services, banking, insurance (17.7 \%); f) Transport, logistics, communication (17.7\%); g) Construction and technical consultancy $(25.3 \%)$; h) Manufacturing (34.9\%)

The percentages above show the differences in the wages between male and female labor across various sectors in India. In other words, every dollar men earn women earn less to the tune of percentage that is depicted in the bracket against each of those sectors. Overall gender wage gap in India is $25.4 \%$. This means the median hourly wage for a women is 25.4 percent less than the median hourly wage for a man.

The current research started with a research question of finding whether gender wage gap has any impact on the GDP growth rate of India. The argument is that gender wage gap discourages women from entering the labor force thereby depriving the 
valuable productivity that would otherwise be utilized toward production of goods and services.

Accordingly, the current chapter analyzes three models with select independent variables and their effect on economic growth with an emphasis on the productivity and the gender wage gap. Concurrently, the chapter employs various statistical measures to confirm the results and test the robustness of the models. The study employed country level data of India from 1970-2010. A time series regression method is used to substantiate the results.

The following models are used in the analysis to substantiate the findings (see Table 3):

1. Model I: economic growth rate change as a dependent variable and capital stock, RPE, human capital, and total labor force as independent variable

2. Model II: economic growth rate change as dependent variable and capital stock, total labor force, human capital and gender wage gap as independent variable.

3. Model III: economic growth rate change as dependent variable and capital stock, total labor force, human capital, RPE, and gender wage gap as independent variable. 
Table 3

Model Comparison

\begin{tabular}{|c|c|c|c|c|c|c|}
\hline & \multicolumn{2}{|c|}{ Model I } & \multicolumn{2}{|c|}{ Model II } & \multicolumn{2}{|c|}{ Model III } \\
\hline & Coefficient & $p$-value & Coefficient & $p$-value & Coefficient & $p$-value \\
\hline const & -3.06 & 0.02 & 1.51 & 0.02 & 0.55 & 0.04 \\
\hline logcapitalstock & 0.90 & $0.01 *$ & 0.83 & $0.02 *$ & 0.99 & $0.01 *$ \\
\hline HumanCapital & 1.24 & $0.04 *$ & $\overline{-2.02}$ & $0.04 *$ & -2.24 & $0.03^{*}$ \\
\hline $\begin{array}{l}\text { Total labour } \\
\text { force(Economically active } \\
\text { population) }\end{array}$ & 1.33 & 0.11 & 1.51 & $0.06^{*}$ & 2.41 & $0.03^{*}$ \\
\hline RelativepoliticalExtraction & 0.29 & $0.04 *$ & - & - & 0.39 & $0.02 *$ \\
\hline Genderwagegap & - & - & -9.41 & $0.03 *$ & -9.03 & $0.02 *$ \\
\hline
\end{tabular}

Dependent variable: Growth rate change of GDP (linear).

*Statistically significant results.

All the models are juxtaposed to compare the coefficient results along with the respective $p$-values. The coefficient scores depict the magnitude of the influence that an independent variable has toward dependent variable whereas the $p$-value indicates whether such influences of independent variable over the dependent variable are significant or not.

The initial Model I was run without including the variable Genderwagegap and the results indicated that all the variables except total labor force had significant positive impact on the economic growth rate change. The variable total labor force did not have any significant impact. Model II was run by replacing RPE variable with the Genderwagegap variable to analyze how the model behaves in the absence of the one another. 
The following section analyzes each of the above models separately to look at the magnitude of the effects of independent variables on the dependent variable of growth rate change.

The initial Model I was run without including the gender wage gap variable (see Table 4). The coefficient scores of Model I show that all the independent variable except for total labor force has significant positive impact on the dependent variable of GDP growth rate change. The coefficient scores indicate that for a unit increase in capital stock variable, there was a significant change in the GDP growth rate change to the tune of .90 times. Similarly, for every unit increase in the human capital variable there was significant GDP growth rate change of 1.24 times. On a same note for every unit increase in the RPE there was an increase in the GDP growth rate change by 0.29 times. The coefficient score of labor force showed that for every unit increase in the total labor force there was an increase of 1.33 score in the GDP growth rate change. However, such a coefficient score was statistically insignificant.

Table 4

Model I Results

\begin{tabular}{|c|c|c|c|}
\hline \multicolumn{3}{|c|}{ Model I } \\
\hline & Coefficient & Std Error & $p$-value \\
\hline const & -3.06 & 0.45 & 0.02 \\
\hline logcapitalstock & 0.90 & 2.80 & $0.01^{*}$ \\
\hline HumanCapital & 1.24 & 0.22 & $0.04^{*}$ \\
\hline $\begin{array}{c}\text { Total labour } \\
\text { force(Economically active } \\
\text { population) }\end{array}$ & 1.33 & 0.81 & 0.11 \\
\hline $\begin{array}{c}\text { RelativepoliticalExtraction } \\
\text { Helatistically significant }\end{array}$ & 0.29 & 1.98 & $0.04^{*}$ \\
\hline
\end{tabular}

*Statistically significant

R-Square $=0.48$ Adjusted R-Square $=0.42$ 
Model II was run by replacing the independent variable of RPE with gender wage gap (see Table 5). The rationale for such replacement is to examine how the independent variable behaves without the presence of another independent variable within the model. Accordingly, the coefficient scores of Model II show that all the independent variables have a significant impact on the dependent variable GDP growth rate change. While the independent variables of capital stock, total labor force had a positive impact on the GDP growth rate change, the other independent variables of human capital and gender wage gap had a negative impact on the GDP growth rate change.

\section{Table 5}

\section{Model II Results}

\begin{tabular}{|c|c|c|c|}
\hline \multicolumn{4}{|c|}{ Model II } \\
\hline & Coefficient & Std Error & $p$-value \\
\hline const & 1.51 & 0.45 & 0.02 \\
\hline logcapitalstock & 0.83 & 0.22 & $0.02^{*}$ \\
\hline HumanCapital & -2.02 & 2.79 & $0.04^{*}$ \\
\hline $\begin{array}{c}\text { Total labour } \\
\text { force(Economically active } \\
\text { population) }\end{array}$ & 1.51 & 0.80 & $0.06^{*}$ \\
\hline \begin{tabular}{c} 
Genderwagegap \\
\hline
\end{tabular} & -9.41 & 1.98 & $0.03^{*}$ \\
\hline
\end{tabular}

*Statistically significant

R- Square $=0.65$ Adjusted R-Square $=0.62$

The coefficient scores showed that for a unit increase in capital stock there was an increase of 0.83 times the GDP growth rate change. Similarly, for a unit increase in the labor force there was 1.5 times increase in the GDP growth rate. On the other hand, for a unit increase in the human capital there was a decrease of -2.02 times the GDP growth 
rate change. The independent variable gender wage gap had a huge negative impact on the GDP growth rate change. For a unit increase in the gender wage gap there was decrease of GDP growth rate change to the tune of -9.4 times.

Model III brings back the variable of RPE and a complete model was run to see the impact on the GDP growth rate change (see Table 6). The coefficient scores indicated that all the independent variables had a significant impact on the GDP growth rate change. While the independent variable of capital stock, total labor force and RPE had a positive impact on the GDP growth rate change, the other independent variables of human capital and gender wage gap had a negative impact on the GDP growth rate change.

Table 6

Model III Results

\begin{tabular}{|c|c|c|c|}
\hline \multicolumn{3}{|c|}{ Model III } \\
\hline & Coefficient & Std. Error & $p$-value \\
\hline const & 0.55 & 1.07 & 0.04 \\
\hline logcapitalstock & 0.99 & 0.23 & $0.01^{*}$ \\
\hline HumanCapital & -2.24 & 0.86 & $0.03^{*}$ \\
\hline $\begin{array}{c}\text { Total labour } \\
\text { force(Economically active } \\
\text { population) }\end{array}$ & 2.41 & 2.84 & $0.03^{*}$ \\
\hline $\begin{array}{c}\text { RelativepoliticalExtraction } \\
\text { Genderwagegap }\end{array}$ & 0.39 & 1.91 & $0.02^{*}$ \\
\hline
\end{tabular}

*Statistically significant

R- Square $=0.71$ Adjusted R-Square $=0.68$

The coefficient score of Model III indicated that for a unit increase in the capital stock, total labor force and RPE there was a positive increase of GDP growth rate change to $.99,2.41$ and .39 respectively. The independent variable of human capital and gender 
wage gap had a negative impact on the GDP growth rate change by -2.2 and -9.03 respectively. All the coefficient scores indicating the influence of independent variable over the dependent variable were statistically significant at $p$ values less than .05

Analysis of the three models revealed that independent variable such as Human Capital, which is positive in the Model I, becomes negative in Model II and Model III with the introduction of gender wage gap variable. The negative impact of the gender wage is so big it influences and pulls back the human capital variable into a negative score. Further it also proves that the negative effect of gender wage gap is so big that it makes the human capital variable have a negative effect on the GDP growth rate change.

The coefficient scores in the regression models represent the mean change in the dependent variable for every unit change in the independent variable while holding all other independent variables in the model constant. The rationale for holding the other variables constant is important since it isolates the role of one variable from all of the others in the model. The size and sign of the coefficient also have significant connotations in the regression model.

Two models (Model I and Model II) with similar independent variables were tested to see the effects of independent variables on the GDP growth rate. The variable, RPE, of Model I was replaced by the variable gender wage gap in Model II to see whether it can be a better model in predicting the GDP growth rate. The results of the analysis indicate that both of the models (Model I and Model II) were better models in terms of significant $p$-value of each independent variable in predicting the GDP growth rate change. Further, the Model III, which includes both variables of RPE and gender 
wage gap, was a good model with all the independent variables that had a significant impact on the dependent variable of GDP growth rate change.

Among the three models the highest R square has been estimated for model III which explains that among all the three models this model explains a relatively stronger relationship existing between the independent variables and the dependent variables. This is the model which also gives significant effect for all the variables and a coefficient of multiple determination of $71 \%$ which means that the regression line approximates the real data point with $71 \%$ accuracy. The relative low $\mathrm{R}$ squared values for Model I and Model II does not necessarily mean the model is weak but since all these models deals with human behavior, these models could reveal important aspects of the relationship between the response and predictor variables. It is important to note here that irrespective of the R square values, the significant regression coefficients reveal the mean change in the dependent variable for unit change in the independent ones while keeping other variables constants.

The current research project started with a hypothesis that RPC (represented in the form of RPE) and gender wage gap will have significant impact on economic growth. Furthermore, it was assumed that the while RPE will have a positive impact on the economic growth rate, gender wage gap would have a negative impact. Accordingly, the data collected and the analyses performed have supported the hypotheses. Another question that was explored through this research was whether the gender wage gap affects the human capital resources and thereby depriving the labor market of valuable 
productive labor. In other words, does the existence of a significant gender wage gap make the human capital less effective and nullify the valuable human capital obtained by the labor force and its productivity in general and female labor force in particular? This is proved in Model II and Model III where the introduction of the gender wage gap variable into the model turns the otherwise positive score of human capital into a significant negative score and similar impact on the growth rate change.

What do these findings mean to Indian economy in particular? What are the policy implications? The next chapter attempts to address these questions and concludes with some of the limitations of the research. 


\section{Chapter 5: Conclusion}

The current study situated within the theoretical framework of endogenous economic growth model explored how the endogenous factors such as capital stock, human capital, and labor affect the economic growth. The study expanded the scope of a regular endogenous economic growth model by including the parameter of political capacity, which is measured in terms of efficient resource extraction capability of the government and the parameter of gender wage gap. Using the case study of India, the research was able to build the model and substantiate the argument.

Gender wage gap is a worldwide phenomenon. The global average wage gap is 40 percent. In other words, the hourly wages of women is 40 percent less than the hourly wages for men (Sampath. G, 2016). In this context, this case study of India provides an important contribution in terms of how an economy can tackle the issue of gender wage gap and its negative impact on economic growth rate change both at the institution level and policy level.

This study aimed to contribute to the existing literature on economic growth and models of economic growth by considering the question of RPC (measured in terms of RPE), labor efficiency contributed by human capital and gender wage gap. For this purpose, the study used the time series regression methods using the dataset of India from the years 1970-2010. This study made the case that the gender wage gap affects utilization of labor productivity by discouraging women to enter labor market and in turn economic growth. In other words, gender wage gap affects the economic growth 
negatively. Further, gender wage gap forces the productive labor out of the labor force. This was evident in Model II and Model III where one of the productivity contributors, which is human capital, shows a negative impact on the economic growth rate change. The main finding of the study is that gender wage gap from an economic perspective affects the labor productivity in the labor market and thereby effects the economic growth of India.

The first question this study addressed was to determine to what extent labor force, human capital and gender wage gap are important to economic growth. The dissertation looks at economic growth rate of India since 1970 to 2010 against the parameter of capital stock, human capital, gender wage gap and RPC measure represented by RPE. The results from looking at the above parameters show that the level of capital stock, human capital, labor force and RPE have a positive and significant effect on the economic growth rate. In other words, any positive increase in the levels of these parameters had resulted in the positive increase of economic growth measured in terms of GDP.

Further, the parameter of gender wage gap showed an inverse relationship to economic growth. In other words, a significant increase in the gender wage gap had negative effect on economic growth indicating that an increase in the level of gender wage gap will affect the economic growth negatively. One of the arguments of the dissertation is that gender wage gap will affect the labor productivity by discouraging the high productive female labor from entering the labor force along with the human capital they possess. The reduction in the productive labor force will have a negative effect on 
the economic growth. The results have shown that this argument is true in the case of India.

The policy implication of these findings is that India is failing to utilize the full potential of its labor productivity. Such an underutilization of labor productivity is reflected in the loss of economic growth. The results have shown that efficiency in terms of RPE have been positive and have a positive influence on economic growth. Policies aimed at increasing the participation of a highly productive female labor force into the labor market will certainly increase the economic growth. This could be possible if measures are introduced at appropriate levels such as hiring and promotion at workplaces to reduce the gender wage gap in India.

Women in India have to fight battles at two levels one at the societal level that demands and requires to do most of the household chores and also raise family at home and second at the employment level where they face discrimination in terms of wages. Such societal pressures combined with the wage disparity at the workplace are discouraging women from entering the labor force and thereby depriving the labor market of much needed productive labor (Schomer, 2010). Hence policy measures are required to encourage female participation in the labor force by formulating rules that facilitate reduction of the gender wage gap. Such policies can take various forms, namely, encouraging work environment for women not only in terms of wages but also in promotions and career path similar to their men counterpart. Policies towards better and affordable child care so that women we are contemplating motherhood or who are already mothers are not deprived and discouraged from re-entering the labor market. 
Similarly, policies towards better paid maternity leave can encourage women to re-enter the labor market. The government policies should also address and explore what is the opportunity cost for women to raise family vis-à-vis enter the job market. At what point women would be willing to enter the labor market along with performing the societal role of a mother and raising children.

The second argument of the dissertation is that efficient government can facilitate economic growth. In the dissertation, the efficiency of the government is measured using the parameter of RPE. The models that are used in the dissertation showed that the above measure of political capacity has been significant in positively influencing the economic growth indicating that the efficiency of the government is a positive indicator of economic growth.

The policy implication of this study can be found across the sectors. First, government should aim for the efficiency in resource extraction from its population leading to better scores on RPE measure. Second, efficient government will be able to better utilize its human resources toward economic activities. This also includes utilization of a highly productive female labor force toward increasing the economic base leading to more economic growth and resource extraction.

Another argument that can be made toward reduction of gender wage gap is that of mutual beneficial relationship between gender wage gap, RPE and economic growth. Increased participation of women in the labor force through reduction of gender wage gap would lead to a more taxable workforce that in turn would yield better RPE scores and economic growth rate. Studies have shown that "Governments of less-developed 
countries extract proportionally less resources from their populations not because their requirements are met (far from it), but because the economic base determined by the per capita productivity of individuals in that society is much smaller" (Kugler \& Tammen, 2012, p. 17).

Participation of female labor force would increase the economic base. It provides an opportunity for the government to increase the efficiency of resource extraction since the productive female labor force that enters the workforce is also a potential contributor of resources in terms of tax payment. This established the mutually beneficial relationship that exists between RPE and reduction of gender wage gap leading to participation of women labor force.

Understanding issues associated with gender wage gap and reduction of such gender wage gap goes a long way in utilization of a productive female force that can contribute to the overall productivity of labor force and economic growth. Further improving political performance is key to not only successful utilization of productive female labor force but also the efficient utilization of resource extraction for which, increased participation of productive female labor force will be helpful. Because the female labor force that participates in the economic activity of production are also potential taxpayers for the income they earn through such productions.

Limitation of this study is that it only uses only one measure of political capacity, namely, RPE. Further research should incorporate the other dimension of political capacity, that is, Relative Political Reach (RPR) and Relative Political Allocation (RPA). RPR measure would be of particular significance since it is one of the measures that 
depicts the efficiency of a government in reaching its population towards achieving the set policy goals. Analysis using Relative Political Reach and Relative Political Allocation measures could provide further insights into how a government, through effective allocation of its resources, is able to tap into the productive labor force (both male and female) and increase the economic growth.

Future research scope based on the current study exists at various levels. First, the same study can be extended to provincial level data to see the regional variation within the Indian economy. Examining the regional variation across India representing formal sector during 2006-2013 years, the state of Uttarakhand has comparatively lower gender wage gap which is $9 \%$. Whereas gender wage gap was highest in the state of Bihar which is at 63 percent. This meant, women in Uttarakhand earned 9 percent less than men whereas women in Bihar earned 63 percent less than men (Jhanavi .R, 2016). It would be interesting to see what factors contribute to such varied difference in gender wage gap differences across the regions. How these factors simultaneously behave in relation to economic growth.

Additionally, future research to explore in terms of gender wage gap in the context of India has to address the issue of caste and class. Similar to regional variations, do we see variations in gender wage gap across caste and class in India. In other words, whether gendered wage gap exist irrespective of caste or class divisions. Stating alternatively, the question is to examine whether gender wage gap exist only among the upper caste or lower caste. Similarly, where gender wage gap exist among the elites or is it limited to middle or lower class of the population. 
Another potential future research study is to do a comparative analysis of at the global level, especially of the emerging economies that exhibit similar characteristics in terms of identical stage of economic development, similar endowments in terms of economic factors of production such as capital and labor. 


\section{References}

Alesina A., \& Perotti, R. (1994). The political economy of growth: A critical survey of the recent literature. The World Bank Economic Review, 8(3), 351-371.

Alksnis, C., Desmarais, S. and Curtis, J. (2008), Workforce Segregation and the Gender Wage Gap: Is "Women's" Work Valued as Highly as "Men's"?. Journal of Applied Social Psychology, 38: 1416-1441.

Arbetman, M., \& Kugler, J. (1997). Political capacity and economic behavior. Boulder, CO: Westview.

Arbetman-Robinowitz, M., \& Johnson, K. (2007, October). Relative political capacity: Empirical and theoretical underpinnings. Paper presented at Claremont Graduate University, Claremont, CA.

Bahl, R.W. (1971). A Regression Approach to Tax Effort and Tax Ratio Analysis. IMF Staff Papers. 18. November.

Barro, R. J., \& Lee J. W. (1993). Losers and winners in economic growth. World Bank Economic Review, Supp. S, 267-297.

Barro, R. J., \& Lee, J. W. (1996). International measures of schooling years and schooling quality. The American Economic Review, 86(2), 218-223.

Basu, K., \& Maertens, A. (2007, Summer). The pattern and causes of economic growth in India. Oxford Review of Economic Policy, 23(2), 143-167.

Bas van, L. (2007). Human Capital and Economic Growth in India, Indonesia, and Japan: A Quantitative Analysis, 1890-2000. Netherlands: Box Press Shop.

Baumol, W. J. (1986). Productivity growth, convergence, and welfare: What the long-run data show. The American Economic Review, 76(5), 1072-1085.

Becker, G. S. (1971). The economics of discrimination. Chicago, IL: University of Chicago Press.

Belser, P., \& Uma, R. (2010). Extending the coverage of minimum wages in India: Simulations from household data. Geneva, Switzerland: International Labor Office.

Bergmann, B. (1974). Occupational segregation, wages and profits when employers discriminate by race and sex. Eastern Economic Journal, 1(2), 103-110. 
Bhaduri, S. N. (2005). Investment, financial constraints and financial liberalization: Some stylized facts from a developing economy, India. Journal of Asian Economics, 16, 704-718.

Bhagwati, J., \& Panagariya, A. (2013). Why growth matters: How economic growth in India reduced poverty and the lessons for other developing countries. New York, NY: Public Affairs.

Bhalla, S. S., \& Kaur, R. (2011). Labour force participation of women in India: Some facts, some queries (Working Paper 40). London, England: London School of Economics and Political Science, Asia Research Centre. Retrieved from http://www2.lse.ac.uk/asiaResearchCentre/ files/ARCWP40-BhallaKaur.pdf

Bhaumik, S. K., \& Chakrabarty, M. (2008). Does move to market have an impact on earnings gap across gender? Some evidence from India. Applied Economic Letters, 15, 601-605.

Carroll, B. J., Conant, R., \& Easton, T. (1987). Private means, public ends. Westport, CT: Praeger.

Chakraborty, C., \& Nunnenkamp, P. (2008). Economic reforms, FDI, and economic growth in India: A sector level analysis. World Development, 36(7), 1192-1212.

Chamarbagwala, R. (2006). Economic liberalization and wage inequality in India. World Development, 34(12), 1997-2015.

Chiou-Wei, S. Z, Zhen, Z., \& Kuo, Y. (2010). Government size and economic growth: An application of the smooth transition regression model. Applied Economics Letters, 17(14), 1405-1415.

Comeau, L. (2003, October). The political economy of growth in Latin America and East Asia: Some empirical evidence. Contemporary Economic Policy, 21(4), 476-489.

Dash, R. K., \& Sahoo, P. (2010, December). Economic growth in India: the role of physical and social infrastructure. Journal of Economic Policy Reform, 13(4), 373-385.

Dash, R. K., \& Sharma, C. (2008). Government expenditure and economic growth: Evidence from India. The IUP Journal of Public Finance, 6(3), 60-69.

Domar, E. (1946). Capital expansion, rate of growth, and employment. Econometrica, 14(2), 137-147.

Democratic Socialists of America. (n.d.) The Gender Pay Gap. Retrived from http://www.dsausa.org/gender_pay_gap 
ECONOMIC RESEARCH, Federal Reserve Bank of St.Louis. (n.d.) Capital Stock at Constant National Prices for India. Retrived from https://fred.stlouisfed.org/series/RKNANPINA666NRUG

Feder, G. (1982). On exports and economic growth. Journal of Development Economics, $12,59-73$.

Feng, Y. (1995). Regime, polity and economic growth: The Latin American experience. Growth and Change, 26(1), 77-104.

Gemmell, N. (1995). Endogenous growth: The Solow Model and human capital. Economics of Planning, 28 (2-3), 169-183.

Gemmell, N. (1996, February). Evaluating the impacts of human capital stocks and accumulation on economic growth: Some new evidence. Oxford Bulletin of Economics and Statistics, 58(1), 9-28.

Goldin, C. (2014). Human Capital. In Claude, D and Haupert, H. (Eds. by) Handbook of Cliometrics.pp.56-84. Department of Economics, Harvard University: Springer Verlag.

Gordon, E. E. (2012, November/December). The global talent change: China, India, and U.S. vie for skilled workers. The Futurist, 46(6), 43-47.

Government of India, Ministry of Labour \& Employment. (n.d.) Annual Report. Retrieved from http://labour.gov.in/annual-reports

Government of India, Ministry of Statistics and Programme Implementation. (n.d.) National Accounts Statistics. Retrived from http://mospi.nic.in/national-account$\underline{\text { statistics-releases-2017 }}$

Grybaite, V. (2006). Analysis of theoretical approaches to gender pay gap. Journal of Business Economics and Management, 7(2), 85-91.

Gupta, V. (2007). India's skilled labor supply: Myth or reality? (Towers Watson Technical Paper No. IND8009). Retrieved from https://ssrn.com/abstract= 1261976 or http://dx.doi.org/10.2139/ssrn.1261976

Guseh, J. S. (1997, January). Government size and economic growth in developing countries: A political economy framework. Journal of Macroeconomics, 19(1), 175-192.

Haberfeld, Y., Moshe, S., \& Audrey, A. (1998, February). Hierarchical linear model for estimating gender-based earnings differentials. Work and Occupations, 25(1), 97-112. 
Harrod, R. F. (1939). An essay in dynamic theory. The Economic Journal, 49(193), 14-33.

Huang, T. (1999). The impact of education and seniority on the male-female wage gap: Is more education the answer? International Journal of Manpower, 20(6), 361-374.

Jahnavi, R. (2016). Gender pay gap is real in India: Here are the numbers to back it up. FIRSTPOST. Retrived from http://www.firstpost.com/india/gender-pay-gap-indianumbers-salary-index-report-2788234.html

Jarrell, S. B., \& Stanley, T. D. (2004, Summer). Declining bias and gender wage discrimination? A meta-regression analysis. The Journal of Human Resources, 39(3), 828-838.

Kohli, A. (2007). State, business, and economic growth in India. Studies in Comparative International Development, 42, 87-114.

Krieckhaus, K. (2002). Reconceptualizing the developmental state: Public savings and economic growth. World Development, 30(10), 1697-1712.

Kugler, J., \& Tammen, R. L. (Ed.). (2012). The performance of nations. Lanham, MD: Rowman and Littlefield.

Kumar, M. (2011). Examining the convergence in the economic growth of Indian states. The IUP Journal of Public Finance, 9(4), 19-27.

Lall, S. V. (2006). Infrastructure and regional growth, growth dynamics and policy relevance for India. Annals of Regional Science, 41, 581-599.

Leftwich, A. (1995, February). Bringing politics back in: Towards a model of the developmental state. The Journal of Development Studies, 31(3), 400-427.

Lips, H. M. (2012). The gender pay gap: challenging the rationalizations: perceived equity, discrimination, and the limits of human capital models. Sex Roles, 1- 17.

Lotz, J.R., and Elliot Morse. (1967). Measuring "Tax Effort” in Developing Countries. IMF Staff Papers. 14.

Mahajan, K., \& Bharat, R. (2012). Caste, female labor supply and the gender wage gap in India: Boserup revisited. Delhi, India: Indian Statistical Institute.

Mallick, J. (2013, Spring). Public expenditure, private investment and income: Evidence in Indian states. The Journal of Developing Areas, 47(1), 181-205. 
Mankiw, N. G., Romer, D., \& Weil, D. (1992). A contribution to the empirics of economic growth. Quarterly Journal of Economics, 107(1), 407-437.

Mbaku, J.M. (1994, Summer). The political economy of development: An empirical analysis of the effects of the institutional framework on economic development. Studies in Comparative International Development, 29(2), 3-21.

Menon, N., \& Rodgers, V. (2009). International trade and the gender wage gap: New evidence from India's manufacturing sector. World Development, 37(5), 965-981.

Mincer, J. (1958, August). Investment in human capital and the personal income distribution, Journal of Political Economy, 66(4), 218-302.

Monster Salary Index. (2016). Gender Pay Report Ready Reckoner. Retrived from http://media.monsterindia.com/logos/research_report/MSI_Gender_Ready_Recko ner_March_2017.pdf

Moralock, E., \& Vitton, P. (1985). The Comparative costs of public and private providers of mass transit. In Urban Transit: The Private challenge to public transportation. Ed by Charles, L. San Francisco, CA: Pacific Institute.

Mukherji, R. (2009, January/March). The state, economic growth, and development in India. India Review, 8(1), 81-106.

Musgrave, R. A. (1983). Who Should Tax, Where, and What? In Tax Assignment in Federal Countries, by Jr. Charles E. McLure. Canberra: Center for Research on Federal Financial Relations, Australian National University.

National Accounts Statistics Sources and Methods. (1989). Capital Stock and Consumption of Fixed Capital. Government of India Ministry of Statistics and Programme Implementation. Retrived from http://mospi.nic.in/sites/default/files/reports_and_publication/cso_national_accou nts/chptwentytwo_nad003.pdf

Nation Master (n.d.) India Labor Stats. Retrived from http://www.nationmaster.com/country-info/profiles/India/Labor

Nelson, J. I. (1992). Social welfare and market economy. Social Science Quarterly, 73, 815-828.

Obiols, M. (n.d.). Countries with highest GDP growth 2017. Retrieved from http://www.gfmag.com/tools/global-database/economic-data/10304-countrieswith-the-highest-gdp-growth-2000-2010.html\#axzz2Jy0WdAAG

Ochsenfeld, F. (2014). Why do women's fields of study pay less? A test of devaluation, human capital, and gender role theory. European Sociological Review, 30, 536 - 548. 
Olsen, R. D., \& Sexton, E. A. (1996, January). Gender differences in the returns to and the acquisition of on-the-job training. Industrial Relations, 35(1), 59-77.

Olson, M., Jr. (1982). The rise and decline of nations: Economic growth, stagflation, and social rigidities. New Haven, CT: Yale University Press.

Oostendorp, R. H. (2009, January). Globalization and the gender wage gap. The World Bank Economic Review, 23(1), 141-161.

Organski, A.F.K., and Jacek Kugler. (1980). The War Ledger. Chicago: Chicago University Press.

Panagariya, A. (2008). India: The emerging giant. New York, NY: The Oxford University Press.

Phelps, E. (1972). The statistical theory of racism and sexism. American Economic Review, 62, 288.

Polachek, S. W. (1987). Occupational segregation and the gender wage gap. Population Research and Policy Review, 6, 47-67.

Poot, J. (2000). A synthesis of empirical research on the impact of government on longrun growth. Growth and Change, 31(4), 516-546.

Pourgerami, A., \& Assane, D. (1992). Macroeconomic determinants of growth: New measurement and evidence on the effect of political freedom. Applied Economics, 24, 129-136.

Pradhan, N. C. (2011). Nexus between capital flows and economic growth: The Indian context. Journal of International Economics, 2(1), 18-37.

Pradhan, R. P. (2011). Financial development, growth, and inflation: The trilateral analysis in India. Journal of Economic and Social Research, 13(2), 45-59.

Priya, L., \& Kumar, S. (2012). Economic growth and impact of service's sector in India. International Journal of Business Management and Economic Research, 3(5), 627-632.

Purfield, C. (2006). Mind the gap: Is economic growth leaving some states behind? (IMF Working Paper 06/103). Washington, DC: International Monetary Fund.

Pye, L. (1966). Aspects of political development. Boston, MA: Little Brown.

Quang, D. M. (2012). Government expenditure and growth in developing countries. Progress in Development, 12(1), 77-82. 
Ram, R. (1986). Government size and economic growth: A new framework and some evidence from cross-section and time-series data. American Economic Review, 76, 191-203.

Ramakrishna, G. (2011). India's trade policy: The impact on economic growth, balance of payments and current account deficit. Journal of International Economics, 2(1), 4-17.

Rao, B. B., \& Vadlamannati, K. C. (2011). The level and growth effects of human capital in India. Applied Economics Letters, 18, 59-62.

Ravallion, M., \& Datt, G. (2002). Why has economic growth been more pro-poor in some states of India than others? Journal of Development Economics, 68, 381-400.

Reilly, B., \& Dutta, P.V. (2005). The Gender Pay Gap and Trade Liberalization: Evidence for India. Poverty Research Unit at Sussex Working Paper, 32.

Reserve Bank of India. (n.d.). Handbook of Statistics on Indian Economy. Retrived from https://rbi.org.in/Scripts/AnnualPublications.aspx?head=Handbook\%20of \%20Statistics\%20on\%20Indian\%20Economy

Riley, P., \& Ravi, K. R. (2016). Corruption and anticorruption: The case of India. Journal of Developing Societies, 32(1), 73-99.

Robinson, D. (1998). Differences in occupational earnings by sex. International Labour Review, 137(1), 3-31.

Rock, M. T. (1993). Twenty-five years of economic development revisited. World Development, 21(11), 1787-1801.

Romer, P. M. (1990). Endogenous technological change. Journal of Political Economy, 98(5), S71-S102.

Sala-i-Martin, X. (1994, April). Cross-sectional regressions and the empirics of economic growth. European Economic Review, 38(3-4), 739-747.

Sampath, G. (2016). Pardon, the gender wage gap is showing. THE HINDU. December 22. Retrived from

http://www.thehindu.com/business/Industry/Pardon-the-gender-wage-gap-isshowing/article16921327.ece

Schomer, K. (2010). Professional women in India: Changing social expectations and best practices for global corporations. New York, NY: Working Mother Media. 
Scully, G.W. (1988). The Institutional Framework and Economic Development. Journal of Political Economy,96(3),652-662.

Seguino, S. (2000a). Accounting for gender in Asian economic growth. Feminist Economics, 6(3), 27-58.

Seguino, S. (2000b). Gender inequality and economic growth: A cross-country analysis. World Development, 28(7), 1211-1230.

Sharma, S. K., \& Sharma, J. (2007). An empirical analysis of growth and structure of service sector in India. VISION: The Journal of Business Perspective, 11(4). doi:10.1177/097226290701100405

Shenhav, Y., \& Haberfeld, Y. (1992). Paradigm uncertainty, gender composition, and earnings inequality in scientific disciplines: A longitudinal study, 1972-1982. Research in the Sociology of Organizations, 10, 141-172.

Singh, A. (2012, March). Inequality of opportunity in earnings and consumption expenditure: The case of Indian men. The Review of Income and Wealth, 58(1), 79-106.

Singh, T. (2003). Effects of exports on productivity and growth in India: An industrybased analysis. Applied Economics, 35, 741-749.

Singh, T. (2008). Financial development and economic growth nexus: A time-series evidence from India. Applied Economics, 40, 1615-1627.

Singh, T. (2010). Service sector and economic growth in India. Applied Economics, 42, 3925-3941.

Singhal, S., Grame, N., \& Nguyen, T. K. (2011). The significance and performance of infrastructure in India. Journal of Property Research, 28(1), 15-34.

Sirowy, L., \& Inkeles, A. (1990). The effects of democracy on economic growth and inequality: A review. Studies in Comparative International Development, 25(1), 126-157.

Skocpol, T. (1979). The potential autonomy of the state. In M. E. Olsen \& M. N. Marger (Eds.), Power in modern societies. pp. 1-328. Boulder, CO: Westview Press.

Solow, R. M. (1956). A contribution to the theory of economic growth. Quarterly Journal of Economics, 70, 65-94.

Spindler C. J., \& Forrester, J. P. (1993, September). Economic development policy: Explaining policy preferences among competing models. Urban Affairs Review, 29(1), 28-53. 
Srivastava, A., \& Sanjay, K. M. (2010). Economic proxies, household consumption and health estimates. Economic and Political Weekly, 45(16), 55-63.

Tam, T. (1996). Reducing the gender gap in an Asian economy: How important is women's increasing work experience? World Development, 24(5), 831-844.

Tang, E. W., \& Hedley, R. A. (1998, September). Distributional coalitions, state strength and economic growth: Towards a comprehensive theory of economic development. Public Choice, 96(3-4), 295-323.

Terrell, K. (1992). Female-male earnings differentials and occupational structure. International Labour Review, 131(4-5), 387-404.

Umar, A. W. (2011). Capital flows, political performance, and development (Doctoral dissertation). Portland State University, Portland, OR.

U.S. Bureau of Labor Statistics. (2012). Labor Market. Retrived from

http://www.bls.gov/fls/chartbook/2012/section2.pdf

Verdier, T. (2002). Models of political economy of growth: A short survey. European Economic Review, 38(3-4), 757-763.

Viswanath, J., Reddy, K. L. N., \& Pandit, V. (2009, January). Human capital contributions to economic growth in India: An aggregate production function analysis. The Indian Journal of Industrial Relations, 44(3), 473-486.

Weichselbaumer, D., \& Winter-Ebmer, R. (2005). A meta-analysis of the international gender wage gap. Journal of Economic Surveys, 19(3), 479-511.

Wellington, A. J. (1994). Accounting for the male/female wage gap among whites: 1976 and 1985. American Sociological Review, 59(6), 839-848.

Websites:

http://www.reforum.org/issues/global-gender-gap

www.mospi.nic.in (Central Statistical Organization and National Accounts Statististics, India)

www.dbie.rbi.org.in

http://indiabudget.nic.in 
www.dss.princeton.edu

https://www.dsausa.org/gender pay gap

https://fred.stlouisfed.org/

http://www.gfmag.com/tools/global-database/economic-data/10304-countries-with-thehighest-gdp-growth-2000-2010.html\#axzz2Jy0WdAAG

http://www.bls.gov/fls/chartbook/2012/section2.pdf www.labour.gov.in ( Ministry of Labour and Employment, Government of India)

http://www.transresearchconsortium.com/ ( Trans National Consortium) 


\section{Appendix A}

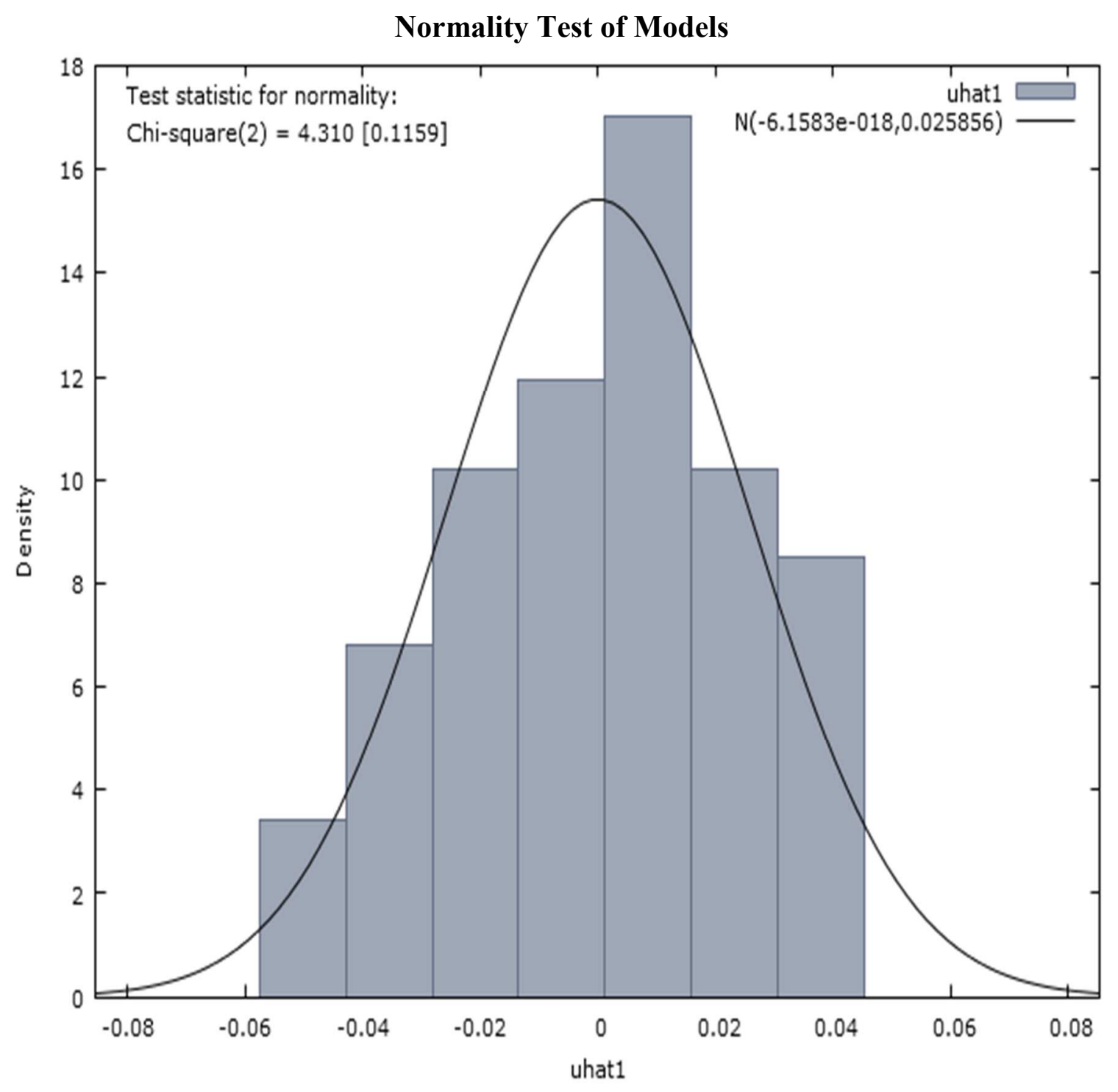




\section{Appendix B}

\section{Statistical Tests for Models}

\section{Variance Inflation Factors (VIF) Scores: Model 3}

Minimum possible value $=1.0$
Values $>10.0$ may indicate a collinearity problem
\[ \begin{array}{rc}\text { d_logcapitalstock } & 1.253 \\ \text { d_HumanCapital } & 1.168 \\ \text { d_RelativepoliticalExtraction } & 1.066 \\ \text { d_TotalLaborForce } & 1.178 \\ \text { d_Genderwagegap } & 1.097\end{array} \]

$\underline{\text { Variance Inflation Factors (VIF) Scores: Model } 2}$

Minimum possible value $=1.0$

Values $>10.0$ may indicate a collinearity problem

d_logcapitalstock $\quad 1.205$

d_HumanCapital $\quad 1.202$

d_RelativepoliticalExtraction 1.065

d_Genderwagegap 1.081

$\operatorname{VIF}(j)=1 /\left(1-R(j)^{\wedge} 2\right)$, where $R(j)$ is the multiple correlation coefficient between variable $\mathrm{j}$ and the other independent variables 
Properties of matrix $X^{\prime} X$ :

$1-$ norm $=42.083358$

Determinant $=9.9262733 \mathrm{e}-012$

Reciprocal condition number $=5.895176 \mathrm{e}-006$

Breusch-Godfrey test: Model 2

Breusch-Godfrey test for first-order autocorrelation OLS, using observations 1971-2010 $(\mathrm{T}=40)$

Dependent variable: Economic growth

$\begin{array}{lccrc} & \text { coefficient } & \text { std. error } & t \text {-ratio } & p \text {-value } \\ \text { - const } & 9.444 & 0.032 & 0.003 & 0.997 \\ \text { d_logcapitalstock } & 0.005 & 0.517 & 0.009 & 0.992 \\ \text { d_HumanCapital } & -0.008 & 1.565 & -0.005 & 0.995 \\ \text { d_RPE } & 0.0004 & 0.075 & 0.006 & 0.995 \\ \text { d_Genderwagegap } & 0.074 & 1.672 & 0.044 & 0.965\end{array}$

Unadjusted R-squared $=0.000438$

Test statistic: $\mathrm{LMF}=0.014462$,

with $p$-value $=\mathrm{P}(\mathrm{F}(1,33)>0.014462)=0.905$

Alternative statistic: $\mathrm{TR}^{\wedge} 2=0.017522$,

with $p$-value $=\mathrm{P}($ Chi-square $(1)>0.017522)=0.895$

Ljung-Box Q' = 0.0157721,

with $p$-value $=P($ Chi-square $(1)>0.0157721)=0.9$ 


\section{Appendix C}

\section{Data Definitions and Sources}

\begin{tabular}{|c|c|c|}
\hline Variables & Description & Sources \\
\hline $\mathrm{K}$ & Capital Stock & $\begin{array}{l}\text { Ministry of Statistics and } \\
\text { Programme Implementation, } \\
\text { Government of India. } \\
\text { (www.mospi.nic.in) } \\
\text { www.mospi.nic.in }\end{array}$ \\
\hline HK & Human Capital & www.mospi.nic.in \\
\hline $\mathrm{LF}$ & Labor Force & Planning Commission of India \\
\hline Y /GDP & $\begin{array}{l}\text { Gross Domestic } \\
\text { Product }\end{array}$ & $\begin{array}{l}\text { Trans Research Consortium } \\
\text { (www.transresearchconsortium.com) }\end{array}$ \\
\hline RPE & $\begin{array}{l}\text { Relative Political } \\
\text { Extraction }\end{array}$ & $\begin{array}{l}\text { Trans Research Consortium } \\
\text { (www.rpcmap.com) } \\
\underline{\text { www.mospi.nic.in }}\end{array}$ \\
\hline RPR & $\begin{array}{l}\text { Relative Political } \\
\text { Reach }\end{array}$ & $\frac{\text { www.mospi.nic.in }}{\underline{\text { www.mospi.nic.in }}}$ \\
\hline $\begin{array}{l}\mathrm{W}_{\mathrm{f}} \\
\mathrm{W}_{\mathrm{m}} \\
\text { WGAP }\end{array}$ & $\begin{array}{l}\text { Female Wage Earning } \\
\text { Male Wage Earning } \\
\text { Gender Wage Gap }\end{array}$ & $\begin{array}{l}\text { Seguino, S (2000a) } \\
\text { Seguino, S (2000a) } \\
\text { Seguino, S (2000a) }\end{array}$ \\
\hline
\end{tabular}

